Article

\title{
Development of Sustainable Timber Construction in Ibero-America: State of the Art in the Region and Identification of Current International Gaps in the Construction Industry
}

\author{
Raúl Araya 1,2,*, Alfredo Guillaumet ${ }^{3}$, Ângela do Valle ${ }^{4}$, María del Pilar Duque ${ }^{5}$, Guillermo Gonzalez ${ }^{6}$ (D), \\ José Manuel Cabrero ${ }^{7}$ (D), Enrique De León ${ }^{8}$, Francisco Castro ${ }^{9}$, Carmen Gutierrez ${ }^{10}{ }^{1 D}$, João Negrão ${ }^{11}$, \\ Laura Moya ${ }^{12}$ and Pablo Guindos $1,2,13,14, * \mathbb{D}$
}

check for updates

Citation: Araya, R.; Guillaumet, A.; do Valle, Â.; Duque, M.d.P.; Gonzalez, G.; Cabrero, J.M.; De León, E.; Castro, F.; Gutierrez, C.; Negrão, J.; et al. Development of Sustainable Timber Construction in Ibero-America: State of the Art in the Region and Identification of Current International Gaps in the Construction Industry. Sustainability 2022, 14, 1170. https://doi.org/ $10.3390 /$ su14031170

Academic Editors: Edwin B. Zea Escamilla and David Trujillo

Received: 14 December 2021

Accepted: 14 January 2022

Published: 20 January 2022

Publisher's Note: MDPI stays neutral with regard to jurisdictional claims in published maps and institutional affiliations.

Copyright: (C) 2022 by the authors. Licensee MDPI, Basel, Switzerland. This article is an open access article distributed under the terms and conditions of the Creative Commons Attribution (CC BY) license (https:// creativecommons.org/licenses/by/ $4.0 /)$.
1 National Excellence Center for the Timber Industry (CENAMAD), Pontificia Universidad Católica de Chile, Santiago 7820436, Chile

2 UC Center for Wood Innovation (CIM UC), Pontificia Universidad Católica de Chile, Santiago 7820436, Chile

3 Department of Civil Engineering, Universidad Tecnológica Nacional, Facultad Regional de Venado Tuerto, Venado Tuerto S2600, Argentina; aaguillaumet@rec.utn.edu.ar

4 Department of Civil Engineering, Universidade Federal de Santa Catarina, Florianópolis 88037-000, Brazil; angela.valle@ufsc.br

5 Department of Civil Engineering, Universidad EIA, Envigado 055428, Colombia; maria.duque27@eia.edu.co

6 School of Engineering, Universidad de Costa Rica, San Pedro 11501, Costa Rica; guillermo.gonzalez@ucr.ac.cr

7 Department of Building Construction, School of Architecture, Universidad de Navarra, 31009 Pamplona, Spain; jcabrero@unav.es

8 Department of Civil Engineering, Faculty of Engineering, Universidad Rafael Landívar, Centroamérica 01016, Guatemala; ejdeleon@url.edu.gt

9 Faculty of Engineering in Wood Technology, Universidad Michoacana de San Nicolás de Hidalgo, Morelia 58000, Mexico; francisco.castro@umich.mx

10 Professional Academic School of Architecture, Continental University, Huancayo 12000, Peru; cgutierreze@continental.edu.pe

11 Department of Civil Engineering, Universidade de Coimbra, 3030-790 Coimbra, Portugal; jhnegrao@dec.uc.pt

12 Faculty of Architecture, Universidad ORT Uruguay, Montevideo 11300, Uruguay; moya@ort.edu.uy

13 Department of Structural and Geotechnical Engineering, Pontificia Universidad Católica de Chile, Santiago 7820436, Chile

14 Department of Engineering Construction and Management, Pontificia Universidad Católica de Chile, Santiago 7820436, Chile

* Correspondence: roaraya@uc.cl (R.A.); pguindos@ing.puc.cl (P.G.)

\begin{abstract}
This article presents the latest developments of the Spanish- and Portuguese-speaking countries of Europe and Latin America towards the development of sustainable timber construction. As most regions related to these countries have not traditionally employed timber as primary construction material, bringing the development of sustainable timber construction into fruition requires a wide range of actions, such as the elaboration of new educational programs, construction of demonstrative buildings, dissemination activities, settlement of public policies, elaboration of new construction codes, and the creation of new certification bodies. This article presents an overview of the state of the development of the different countries of Ibero-America, showing a very uneven development in the region. In addition to national analyses, a perception survey of 233 professionals from different countries was conducted, allowing for the identification of good practices, present gaps, and opportunities, as well as barriers for developing sustainable timber construction. It is concluded that in order to promote the development of the timber construction industry in the region, it is necessary to progress on regulatory, cultural, and material availability issues, where international experience, demonstrative buildings, and the implementation of public policies are crucial.
\end{abstract}

Keywords: Ibero-America; sustainable construction; timber construction; industrialization; educational program; public policy; user perception 


\section{Introduction}

Ibero-America comprises a region in the world that contains 22 countries: 19 Spanishand Portuguese-speaking South American countries, and 3 from the Iberian PeninsulaSpain, Portugal, and Andorra. Of the world total, Ibero-American countries are home to $8.9 \%$ of the population and contribute $7.4 \%$ of the world economy [1,2]. Although the land area of these countries is $15.3 \%$ of the world total, this percentage is increased regarding forests, since the forest area of Ibero-America corresponds to $22.3 \%$ of the world total [3]. A breakdown of the percentages by country is presented in Table 1. Although the percentage of forest area in the Ibero-American region is close to a quarter of the world total, most of the countries in the region do not use wood as the main construction material, but rather other materials such as reinforced concrete or masonry. Exceptions to this are certain regions of Spain and Portugal in Europe, and Brazil and Chile in Latin America, which were strongly influenced by the European cultural heritage of the colonization process in the area. Figure 1 shows an example of wood architecture that successfully fuses European and indigenous traditions, corresponding to the case of the Chilean churches located in Chiloé [4]. Together with the influence of countries with a long tradition of wood construction, another differentiating characteristic is the introduction of fast-growing wood species in several areas in Ibero-America. Their rapid growth rate often includes timber of lower structural quality [5], but the renewable potential of wood as a building material can be maximized, as the typical duration of tree felling ranges from one-half to one-third of the building's service life. Fast-growing species also have advantages for the manufacture of mass timber products, as wood quality is not usually a limiting design parameter for them [6]. Another distinguishing characteristic of timber development in many IberoAmerican countries is that timber has typically been used for low-income and emergency housing. In its design, the quality of the products and the technologies used in these circumstances have commonly been very deficient, one reason why wood construction is commonly considered low-quality and poor housing, unlike in European and North American countries with greater constructive tradition in the use of the material [7].

Although timber has not traditionally been used as prevailing material in IberoAmerica, the great potential of timber in the context of sustainable construction has been reported in many sources. Indeed, timber constructions are typically related to lower embodied carbon emissions and lower energetic consumptions [8], and, as stated before, the renewable potential is especially high due to rapid growth cycles in these specific countries. Therefore, in this study a comprehensive review of the state of the art of timber construction development in 11 Ibero-American countries (Argentina, Brazil, Colombia, Costa Rica, Chile, Spain, Guatemala, Mexico, Peru, Portugal, and Uruguay) was accomplished. The current state of the art of sustainable wood construction was analyzed, as well as the implementation of educational programs, iconic buildings, public policies, construction, and design standards. In addition, a survey of the perception of the users of wood in construction was carried out in order to analyze the perception of people as an important aspect regarding the development of construction, directly relating to aspects such as user comfort, with the design process itself [9].

The following sections provide first an overview of the use of wood in construction, ranging from the procurement of the forest resource to the details of its use throughout the Ibero-American region. The second part of the article presents the details regarding the development of timber construction in the different Ibero-American countries. The third and last part of the article details the results of a survey perception and a global analysis and outlook. 
Table 1. Amount of world population, surface area, forest area, and gross domestic product of Ibero-American countries in the world (Own elaboration, based on [1-3]).

\begin{tabular}{ccccc}
\hline & \% Population & \% Surface Area & \% Forest Area & \% GDP \\
\hline Andorra & 0.001 & 0.0003 & 0.0004 & 0.004 \\
Argentina & 0.60 & 2.07 & 0.65 & 0.45 \\
Bolivia & 0.15 & 0.82 & 1.33 & 0.04 \\
Brazil & 2.77 & 6.33 & 12.07 & 1.71 \\
Colombia & 0.65 & 0.85 & 1.43 & 0.32 \\
Costa Rica & 0.07 & 0.04 & 0.07 & 0.07 \\
Cuba & 0.14 & 0.08 & 0.08 & 0.30 \\
Chile & 0.24 & 0.56 & 0.45 & 0.09 \\
Dominican & 0.14 & 0.04 & 0.05 & 0.12 \\
Republic & & & 0.30 & 0.03 \\
Ecuador & 0.22 & 0.19 & 0.01 & 1.51 \\
El Salvador & 0.08 & 0.02 & 0.45 & 0.09 \\
Spain & 0.61 & 0.38 & 0.09 & 0.03 \\
Guatemala & 0.23 & 0.08 & 0.11 & 1.27 \\
Honduras & 0.12 & 0.08 & 1.62 & 0.01 \\
Mexico & 1.69 & 1.46 & 0.08 & 0.06 \\
Nicaragua & 0.08 & 0.10 & 0.11 & 0.04 \\
Panama & 0.05 & 0.06 & 0.36 & 0.24 \\
Paraguay & 0.09 & 0.30 & 1.81 & 0.27 \\
Peru & 0.42 & 0.96 & 0.08 & 0.06 \\
Portugal & 0.13 & 0.07 & 0.05 & 0.57 \\
Uruguay & 0.04 & 0.13 & 1.14 & 7.42 \\
Venezuela & 0.38 & 0.68 & 22.32 & \\
\hline Ibero-America & 8.92 & 15.27 & & \\
\hline
\end{tabular}

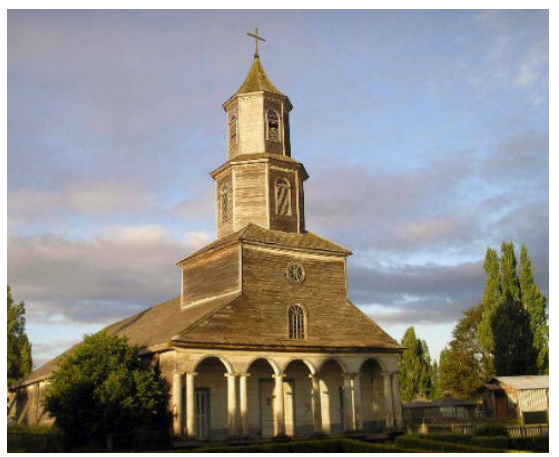

(a)

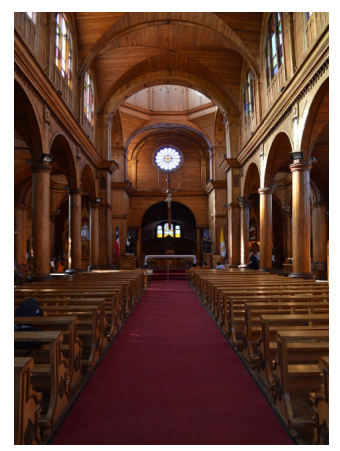

(b)

Figure 1. Examples of Chilean wooden churches [4]: (a) facade; (b) inner view.

\section{Methodology}

The main objective of the research was to identify the gaps and opportunities to foster the use of sustainable timber construction in Ibero-America. For this purpose, the article is divided into two main topics: one focused on contextualizing the global and local reality of each country in the region, and a second one focused on a perception study for users.

\subsection{Global and Regional Analysis}

A review of the global state of the art of forest resources and generic aspects of the region, such as forest area, timber species, or types of plantations, among others, was carried out. The regional analyses in the article were conducted by a panel of international experts and academics from the 11 Ibero-American countries studied, reviewing at the local level the state of the art of the educational programs, public policies, construction codes, and demonstrative buildings, among others. 


\subsection{Survey Design}

The profile of the respondents is of professionals who graduated in or are in training in the area of timber construction or in professional careers related to the timber industry (builders, architects, engineers, foresters, etc.). They were selected from the databases of the UC Center for Wood Innovation (CIM UC), Cadwork Ibérica \& Latinoamérica, AMATA S.A., and the dissemination was carried out by the researchers in professional courses associated with wood construction.

The survey itself was composed of a total of 15 questions. Table 2 shows the details of the questions, which were grouped into 4 study factors: the first study factor was associated with the respondent's personal data and previous experience with wood as a construction material. The second factor corresponded to the user's perception of the use of the material, identifying both positive and negative aspects of its use. Then, for the third factor, a couple of questions associated with the perception of sustainability of the material were implemented, and finally, the fourth factor was associated with professional training on topics associated with the use of wood in construction.

Table 2. Details of the survey questions.

\begin{tabular}{|c|c|}
\hline Study Factors & Question Topics \\
\hline Personal data & $\begin{array}{l}\text { 01. Age } \\
\text { 02. Country } \\
\text { 03. Professional area of study } \\
\text { 04. Level of knowledge of the wood material } \\
\text { 05. Uses you have made of wood in your professional practice }\end{array}$ \\
\hline Perception data & $\begin{array}{l}\text { 06. Materiality preference for a house } \\
\text { 07. Materiality preference for an apartment building } \\
\text { 08. Perception of attributes that hinder wood construction } \\
\text { 09. Perception of attributes that benefit wood construction }\end{array}$ \\
\hline Sustainability & $\begin{array}{l}\text { 10. Promoting the use of more sustainable building materials } \\
\text { 11. Use of sustainable building materials to counteract the negative } \\
\text { effects of climate change }\end{array}$ \\
\hline $\begin{array}{l}\text { Professional } \\
\text { training }\end{array}$ & $\begin{array}{l}\text { 12. Participation in a training program oriented toward the use of wood } \\
\text { 13. Type of wood-related knowledge that you would like to acquire } \\
\text { 14. Type of preferred channels to acquire the knowledge } \\
\text { 15. Format of the channels to acquire the knowledge }\end{array}$ \\
\hline
\end{tabular}

Together with the total analysis of the Ibero-American results, a comparative analysis of these results with the results at the regional level was carried out based on the groups in Figure 2 in order to identify possible gaps at the cultural or geographic level. For this purpose, group A, corresponding to Spain and Portugal, was identified as the European group of the region. Then groups B and C, composed of the Latin American countries, were identified. The grouping of countries into groups B or C depended exclusively on the geographical area of the region and the proportion of land covered by forest plantations [3], according to Figure 2. Thus, group B was composed of the southernmost countries of America: Argentina, Chile, Paraguay, and Uruguay, which share a proportion of land covered by forest plantations of less than 50\%, whereas group C, composed of Brazil, Colombia, Costa Rica, Ecuador, El Salvador, Guatemala, Mexico, Panama, and Peru, exceed $50 \%$ of land covered by forest plantations. 


\section{Ibero-American groups designation:}

Group A: Spain, Portugal

Group B: Argentina, Chile, Paraguay, Uruguay

Group C: Brazil, Colombia, Costa Rica, Ecuador, El Salvador, Guatemala, Mexico, Panama, Peru

Figure 2. Designation of Ibero-American country groups for survey analysis. Grouped on the basis of similar forest areas (Adapted with permission from Ref. [3]. 2020 FAO).

\section{The Timber Resource}

Wood is a renewable natural material whose principal means of production is through the planting of forests used for its processing. Table 3 shows the proportion of planted forests in different regions of the world according to the Food and Agriculture Organization of the United Nations (FAO) [3]. Within the total planted forests for each region, a distinction is made between forest plantations, generally of one or two species, intended to produce timber, fiber, and derived products, following planting and maturing criteria for their proper maintenance and preservation. Other planted forests that do not fall into this category are plantations for ecosystem restoration. As shown in Table 3, in South America almost all planted forests correspond to forests destined for plantation forestry, in contrast to the European region, where practically no forest resources are extracted in most forests. Part of this is because forest resources derived from forest plantations in countries lacking a timber construction tradition are associated with a market economy based on exports, mainly of pulp and sawn timber. To avoid overexploitation of the forest resource, in terms of deforestation and preservation, these forests must guarantee sustainable management in such a way as to preserve biological diversity and benefit the lives of local populations and workers while ensuring economic viability $[10,11]$. These certification bodies include the Forest Stewardship Council (FSC) and the Programme for the Endorsement of Forest Certification (PEFC). During 2019, a total of 426 million hectares of forests were certified by one or both systems [3], with more than $60 \%$ of these certifications concentrated in the regions of Canada, the Russian Federation, and the United States of America. Another important factor for forest resource management is the economic importance of forest resources in exporting countries. As a result, during the last few decades, many regions have been working with fast-growing plantations. Table 4 shows some of the largest fast-growing plantations in Ibero-American countries [12].

Table 3. Proportion of planted forest by world region, 2020 (Own elaboration, based on [3]).

\begin{tabular}{ccc}
\hline & \multicolumn{2}{c}{ Planted Forest } \\
\hline & Plantation Forest & Other Planted Forest \\
\hline Africa & $67 \%$ & $33 \%$ \\
Asia & $59 \%$ & $41 \%$ \\
Europe & $6 \%$ & $94 \%$ \\
North and Central America & $32 \%$ & $68 \%$ \\
Oceania & $91 \%$ & $9 \%$ \\
South America & $99 \%$ & $1 \%$ \\
\hline Ibero-America & $45 \%$ & $55 \%$
\end{tabular}


Table 4. Fast-growing species plantations, 2003 (adapted data from [12]).

\begin{tabular}{|c|c|c|c|c|}
\hline Species & $\begin{array}{l}\text { Mean Annual } \\
\text { Increment } \\
\left(\mathrm{m}^{3} / \mathrm{ha} / \text { Year }\right)\end{array}$ & $\begin{array}{l}\text { Time to Reach } \\
\text { Maturity (Years) }\end{array}$ & $\begin{array}{l}\text { Estimated Extent } \\
\text { Fast-Wood Plantations } \\
\text { Only (1000 ha) }\end{array}$ & Main Countries \\
\hline $\begin{array}{l}\text { Eucalyptus grandis and } \\
\text { various eucalyptus } \\
\text { hybrids }\end{array}$ & $15-40$ & $5-15$ & \pm 3.700 & $\begin{array}{l}\text { Brazil, South Africa, Uruguay, } \\
\text { India, Congo, Zimbabwe }\end{array}$ \\
\hline Temperate eucalyptus & $5-18$ & $10-15$ & \pm 1.900 & $\begin{array}{l}\text { Chile, Portugal, Northwest } \\
\text { Spain, Argentina, Uruguay, } \\
\text { South Africa, Australia }\end{array}$ \\
\hline Caribbean pines & $8-20$ & $10-18$ & \pm 300 & Venezuela \\
\hline Gmelina arborea & $15-35$ & $12-20$ & \pm 100 & $\begin{array}{c}\text { Costa Rica, Malaysia, } \\
\text { Solomon Islands }\end{array}$ \\
\hline
\end{tabular}

In the construction field, the use of forest resources as construction material in the different areas of Ibero-America is limited by the state of progress of each area, not only in terms of raw material acquisition, but also due to the lack of development in terms of regulations for its characterization and classification for structural use, which hinders the use of the material on site because the calculators lack the necessary technical basis to make their designs under the appropriate standards.

\section{The Timber Construction Share}

Although not all countries in the region have made the same degree of progress in their wood construction industries, they all have common barriers to overcome in terms of product certification, modification of current design codes, the need for public policies that promote the use of sustainable materials, or cultural barriers resulting from social stigmas attributed to the deficiencies of wood as an effective construction material in contrast to traditional building materials. Regarding wood as a construction material, the main construction systems used are light-frame platform systems, post-and-beam systems, glulam, and, to a lesser extent, massive systems like CLT [7], where pine, eucalyptus, and, to a lesser degree, some imported species like redwood, spruce, or birch are the major species used in Ibero-America for construction [13-20].

Nevertheless, areas in Latin America where wood has been used more frequently as the main construction material in housing or mid-rise buildings are scarce. According to available data, Ibero-American countries have a timber construction share between $2 \%$ and 20\% [21-23]. In most areas of Latin America, timber has not traditionally been the main construction material, in comparison with Northern European or North American countries. An exception may be the region of Chile, where timber construction share values are about $20 \%$ [23], but still lower than other traditional construction materials such as reinforced concrete or masonry.

\section{National Analyses}

In this section, a review of the current state of engineering and sustainable timber construction, as well as educational programs, emblematic buildings, public policies, and construction and design standards, will be presented for each country.

\subsection{Argentina}

Argentina does not have a tradition in sustainable wood construction, but it does have 1.3 million hectares of cultivated forests, with species suitable for use in structural components [24]. The Mesopotamian region is the main forestry-industrial basin, with species such as Pinus sp. and Eucalyptus sp., whereas the Paraná River Delta is the wood supplier for Populus sp., all species characterized by their rapid growth [25]. For a little more than 20 years, universities, companies, and state organizations have been working to promote the development of the timber construction industry. For safety in structures, 
in 2016 the first Argentine Regulation for Wood Structures INTI-CIRSOC 601/2016 was approved based on the allowable stress design method (ASD) [26]. It comprises the requirements for the design and safety of buildings and a supplement with the visual classification method and the admissible values for five species from plantation forests. The Argentinean Institute for Standardization and Certification (IRAM) develops the technical standards for the testing of structural wood, being particularly notorious the standards for the manufacturing and control of glued, laminated beams [27]. This task is supported by the work of the few research groups dedicated to the characterization of wood from implanted forests with proposals of methods for visual classification, determination of characteristic values, and others that promote construction, especially in light framework. From the Faculties of Forest Sciences of the different universities and the National Institute of Agricultural Technology (INTA), studies have been carried out to improve the quality of forests, the wood that is extracted from them, and the best use of it. According to data from the Construction Economic Analysis Forum of 2019, the housing deficit affected $3,142,447$ families residing in precarious or overcrowded houses [28,29]. The national government contributes to promoting construction with wood through different resolutions, establishing that $10 \%$ of the national housing plans be made of wood, recognizing the "construction system in wood lattice" as a "traditional" construction system and eliminating the requirement of the Certificate of Technical Aptitude (CAT) for the projects (Resolution 3-E/2018), approving the minimum quality standards for low-income housing (Resolution 9-E/2017), and setting guidelines for construction [30,31]. There are still many tasks to perform to enhance timber construction, especially in the quality controls of the homes currently offered, incentives in the construction plans with state funding for the use of this material, and regulations that contemplate the use of wood in construction due to its effect on climate change. In most universities, the curricula of civil engineering and architecture courses do not include specific subjects dedicated to construction with wood or the structural design of wooden structures. In general, to achieve the proficiency required by current academic standards, the contents are included as complements in subjects where the main study material is different, and the level depends largely on the profile of the teaching team. In recent years, there has been growth in the offering of specific postgraduate trainings, diplomas, and technical degrees; however, an impact at the national level is yet to be seen.

\subsection{Brazil}

Brazil has a long tradition of construction with concrete, but the use of timber for roofing structures is common. In the southern part of the country, where there is a strong colonization influence from Germans, Austrians, and Hungarians, there are some examples of ancient wooden buildings [32]. Specific educational programs completely dedicated to timber construction do not exist. Some universities offer classes in timber construction and structures in architecture and engineering, but there is a lack of it in most curricula. Some universities with a tradition in timber construction classes include the University of São Paulo, the University of Brasília, Federal University of Santa Catarina, Mackenzie Presbyterian University, and Federal University of Minas Gerais. Recently, there has been an increase in the number of timber construction companies using glulam and CLT techniques, and more examples of buildings with larger spans and heights. However, the tallest wood-framed building ever made in Brazil has only four floors. Two remarkable demonstrative timber buildings in Brazil are the social light-frame housing building in Pinhais City in Paraná State and the Dengo chocolate factory building with CLT and glulam in São Paulo City. The timber structure with the largest span in Brazil is in Shopping Iguatemi in Fortaleza (See Figure 3), which comprises a glulam roof with a $48 \mathrm{~m}$ span and $18 \mathrm{~m}$ height $[33,34]$. 


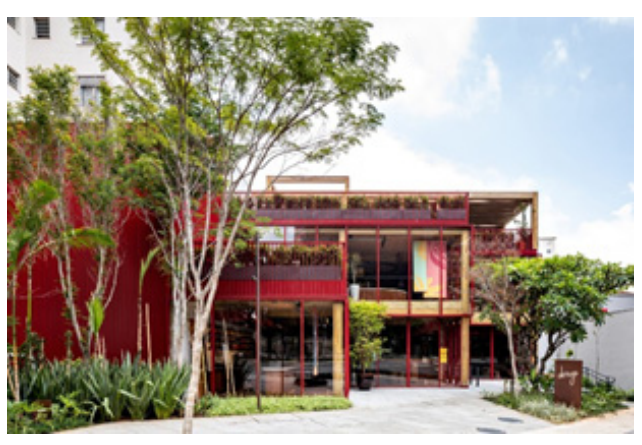

(a)

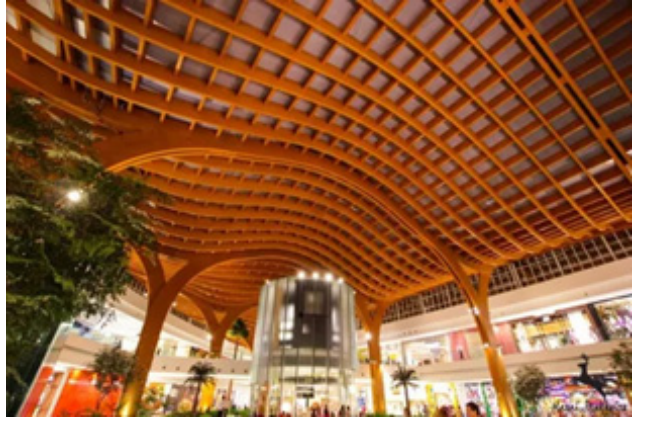

(b)

Figure 3. Remarkable demonstrative buildings in Brazil: (a) Dengo chocolate factory in São Paulo; (b) Shopping Iguatemi in Fortaleza.

The Brazilian timber structural code ABNT NBR7190 [35] is under review and the new edition may be available in 2022, with updates for the calculation of the fire resistance of timber structures and test methods for structural parts. The fundamentals of this code address the Ultimate Limit State Design (ULS) of Europe, EN 1995 [36]. One of the greatest problems for building with timber in Brazil is the absence of public policies and longterm planning. The supply of sawn wood nowadays is oriented towards exportation and Brazilian builders face difficulties finding material to work with. A significant additional difficulty for developing timber construction is the lack of structural beams classified according to the requirements of the codes. Despite the Brazilian codes establishing structural timber grades, the market ignores them and uses non-classified material. Even the major companies do not have the habit of using classified timber products. Sawn timber producers state that consumers do not require structural-graded timber, so they see no motivation to invest in material classification.

\subsection{Colombia}

Timber construction in Colombia peaked in colonial times and lasted until the middle of the last century; however, in the following years, reinforced concrete and masonry relegated wood construction, keeping its use mainly for roofs and self-constructed housing. In 1975, with the participation in the Cartagena Agreement Board and the launch of the PADT-REFORT project, the incorporation of Andean tropical forests into the economy was promoted to include them as a housing solution [37]. With the launching of the Andean Group's Wood Design Manual in 1984, there was a revival of interest in wood construction, which resulted in the birth of small glulam construction and manufacturing companies. Some companies started to reforest and invest in sustainable plantations [38]. However, this incorporation of Andean forests into the economy, which at the time was thought to be a solution, is now becoming a worrying situation for the forestry industry. Illegal logging of forests- $42 \%$ of total wood production, equivalent to 2 million $\mathrm{m}^{3}$ of $\operatorname{logs}$ from natural forests, and the level of illegality in the mobilization of wood in Colombia of between $71 \%$ and $80 \%$ - has threatened the subsistence of some species [39]. As a political counteract, in 2016 the government launched new policies to control deforestation, and improve forest governance and sustainable sector planning and development, among which is the sustainable use of forests [40], which constitutes a policy of forest protection, but not a desire to increase the production of wood from plantations and reforestation. With an annual per capita consumption of wood of $0.18 \mathrm{~m}^{3}$ [41], Colombia is located below countries such as Ecuador, Uruguay, and Chile. According to the FAO [42], the consumption balance was negative for the year 2019 and the production of wood and its derivatives reached USD 84.5 million, whereas imports were USD 256.6 million [43]. The reborn interest in wood in the 1980s did not last over time. Wood construction was stagnant due to the limited availability of the material, the limited knowledge of its design and construction, and the poor perception of the material as a constructive solution by users. 
In terms of professional training, there are forestry engineering programs; however, in the faculties of architecture and civil engineering, no wood construction courses are taught. Only since 2021 have two extension courses in design and construction with wood been offered by University Nacional and EIA University [44]. Current regulations for the design of wooden structures only allow two-story buildings or industrial-type structures [45]. Regarding the structural design methods, the Colombian design approach is based on the Andean Group Wood Design Manual (1984) and U.S. NDS-2005 [46]. It is expected that by 2022 the proposal to update the regulations proposed in document AIS-100, Title G, of the Colombian Association of Seismic Engineering, based on the NDS-2018, SDPWS-2021 and Eurocode 8, will be accepted [47-49]. The proposed regulation does not have its own basic research, but constitutes an adaptation of foreign regulations to the national context and will allow for the construction of medium-rise buildings in light frameworks (up to $18 \mathrm{~m}$ ) and the use of CLT. In the local market (see Figure 4), prefabricated wooden houses are offered at competitive prices with respect to other materials that are used as country cabins or as luxury houses. Temporary housing camps have also been built in wood in hydroelectric projects, rural schools, service buildings, and rural social housing solutions.

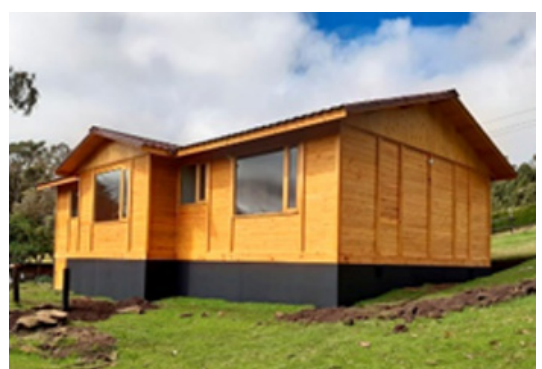

(a)

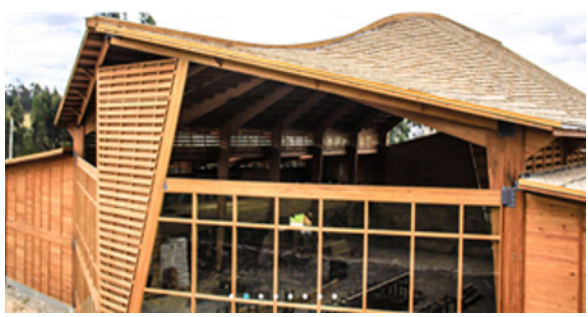

(c)

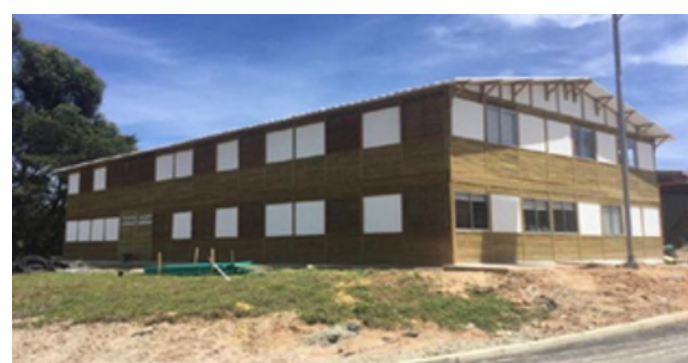

(b)

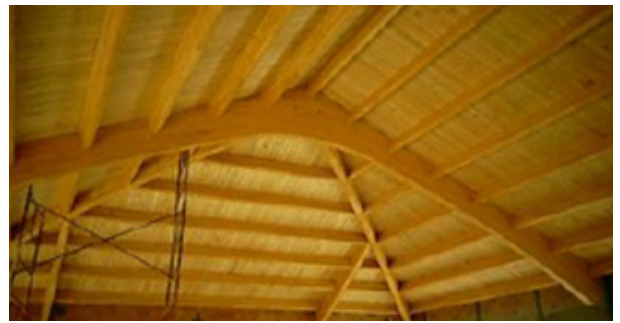

(d)

Figure 4. Wooden constructions in Colombia: (a) prefabricated house (assembly workshop); (b) Devimed building; (c) Sesquilé cellar (assembly workshop); (d) glulam roofing structure (Maderinsa).

\subsection{Costa Rica}

In Costa Rica, the use of timber for construction was very successful in the first half of the 20th century. Most of the houses used timber as a structural component and for finishes. However, it diminished drastically during the second half due to the use of new, upcoming materials such as concrete blocks, but mostly due to the accelerated deforestation of natural forests, leaving the use of timber only for finishes and miscellaneous structures. In the 1990s and the last two decades, reforestation has been increasing and specific plantations can be found in different regions of the country [50]. In addition, since there are no standards for timber products, the country has been importing them to supply the need. In the current wood industry (total volume of 814.731 cubic meters), pallets are the most used product and represent $51.2 \%$ of the market. Wood for construction is only $22.7 \%$, exports $14.3 \%$, furniture $9.2 \%$, and others $2.1 \%$. Of the total used for construction, $42.5 \%$ is for concrete formwork, $34.5 \%$ for lumber, and the rest for finishes such as floors, roofs, and molding [51].

Concerning educational programs, most of them exist in public universities. For instance, the National University (Universidad Nacional) and Technological Institute (Instituto Tecnológico) offer Forestry Engineering, which includes courses about the technology 
of wood [52]. On the other hand, the University of Costa Rica (Universidad de Costa Rica) is the only one offering courses in timber as a structural material. The School of Civil Engineering at this university is starting to offer the elective course "Design of Wood Structures" both in undergraduate and graduate programs. This course deals with the fundamentals of wood as a construction material and its structural design, including beams, columns, diaphragms, shear walls, connections, and structures [53]. During the last decade, the research program in these universities has increased significantly. Figure 5 shows an experimental setup carried out at the University of Costa Rica in which moment connections with local materials were studied [54].

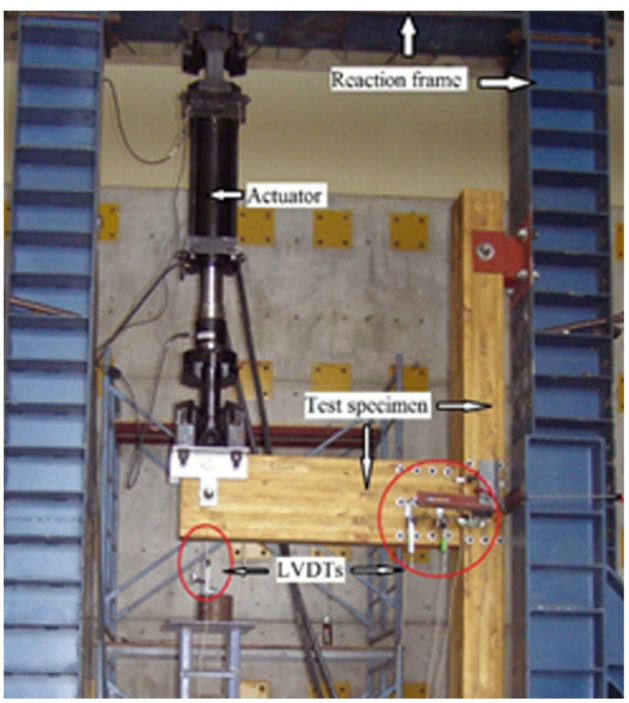

Figure 5. Experimental setup of a moment-resistant connection [54].

As mentioned earlier, the use of timber in construction has increased in the last few decades due to the importation of classified products from which glulam is produced. However, it is still low in comparison with traditional construction materials such as reinforced concrete or masonry. Figure 6 shows Cueva de Luz, a four-story building and part of a roof structure at the Civil Engineers Association.

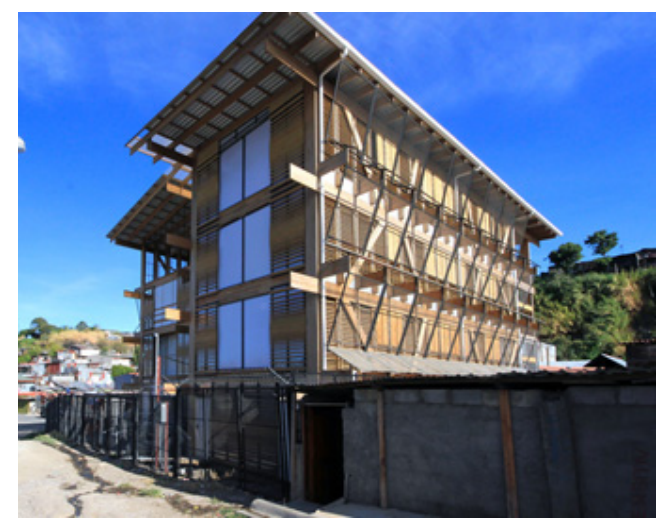

(a)

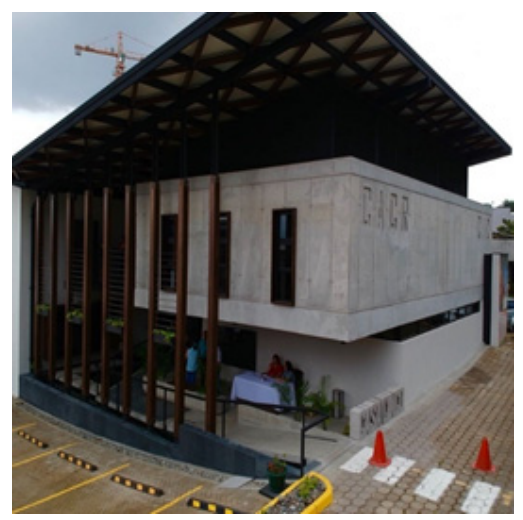

(b)

Figure 6. Examples of timber structures in Costa Rica: (a) Cueva de Luz building in San José; (b) Casa 5 at the Engineers and Architects Federation of Costa Rica.

Regarding public policies, there are a few laws that favor projects that are sustainable, which may come to regard the use of timber as an advantage. In 2008, the Costa Rican Seismic Code [55] included a chapter about timber structures based on the Special Design Provisions for Wind and Seismic published by the American Wood Council [56]. The 
structural design must be based on the National Design Specification [46], with certain considerations. Around the same year, the Institute of Technical Standards of Costa Rica (INTECO) started to develop standards, based on North American standards, for wood and wood products, including structural classification, glulam, plywood, and other products. Despite this effort, it has been a hard task to train and convince the market of the importance of standardization. Therefore, engineers do not currently have the necessary tools to specify products for structural applications.

\subsection{Chile}

Chile has a long tradition of timber construction, especially in the southern part of the country. Educational programs for timber construction have existed at the University of Bio-Bio in Concepción since 1969 [57]. Subsequently, timber construction has been taught at several universities, including the University of Concepción, University of Santiago, University of Chile, and Pontifical Catholic University of Chile, among others. Typically, timber education has been a subject of high interest in schools of architecture, but it has not been implemented with the same intensity in schools of civil engineering. However, during the last few years, there has been a significant increase in timber subjects in schools of civil engineering, including courses at the undergraduate and postgraduate levels, and a significant amount of pedagogical material has been published [6,7,58]. Yet, timber subjects remain elective subjects. In the professional training field, there have been master's programs in Concepción since 1969, but during the last five years the offer has rapidly increased, and nowadays there are three postgraduate diplomas at different locations in the country. Research on timber engineering has been performed by isolated groups dispersed around the country. Among the most active groups are the Forestry Institute of Chile (INFOR) [59] and university research groups such as the UC Center for Wood Innovation (CIM UC), Polomadera, the timber engineering group from the University of Concepción and the group from the University of Santiago. Recently, most of them have joined to create the National Excellence Center for the Timber Industry (CENAMAD) in order to jointly promote and research the use of timber.

Currently, the timber construction share in Chile amounts to about 20\% [23]. However, most of it only covers unfamiliar dwellings. During the last few years, a major national effort has been devoted to enabling mid-rise timber construction. In this context, a large national project has been conducted to determine the seismic design factors for light-frame as well as CLT construction [60]. These two important projects have also been empowered by a national project to determine the lateral and gravitational design of slabs [61]; the creation of a Building Information Modeling database, which has yielded to a constructive components platform [62]; and a project to create a national fire design standard for timber constructions that will be incorporated into actual codes [20]. As a result, significant advancement of standard codes has been achieved and several demonstrative mid-rise buildings have been constructed. These new standards enrich the already existing standards regarding timber classification, characterization, and structural design, which generates a set of regulations that allows for the design of any type of timber building (without any restriction in height) around the country. In general, the structural standards of Chile are based on the National Design Standard for wood construction in the U.S.A [46], with the difference that only the Allowable Stress Design (ASD) method is allowed but not Load and Resistance Factor Design (LRFD). The lateral design of assembly is based on the Special Design Provisions for Wind and Seismic [56], whereas certain aspects of design are based on European rules, such as the fire design standard [63], as well as the procedure for the calculation of characteristic properties of laminates, among others. This mixture of standards often requires the application of probabilistic coefficients for strength conversion. In the last three years, two six-story building projects have been completed in the country, namely, the Complejo los Bronces and the Peñuelas Experimental Tower (see Figure 7 [64]). The latter consists of a non-residential demonstrative tower that allows contractors and the general public to experience and touch a multistory building. Furthermore, the tower 
is fully monitored with structural and non-structural devices to assess its performance. Apart from the Peñuelas tower, there have been other relevant iconic projects, including several hundred social complexes, such as the Oasis de Chañaral, the multistory project Horizonte del Pacífico, and the Paso de Los Libertadores, among others. These actions have been necessary for convincing the general public and real estate companies that mid-rise timber buildings are a feasible national solution, and currently several other buildings of that height and higher are being developed.

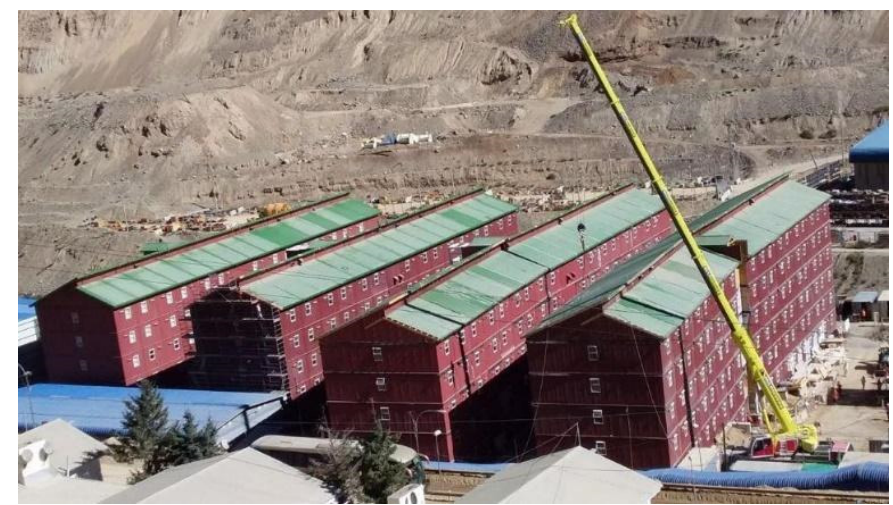

(a)

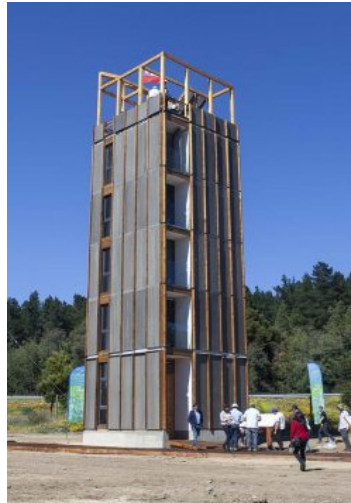

(b)

Figure 7. Some recent iconic timber constructions in Chile: (a) Campamento Los Bronces; (b) Peñuelas Experimental Tower.

Although most plantations in Chile are certified as sustainable forests [65], one important difficulty for developing timber construction has been the lack of certification regarding the structural quality of timber. Only a few major companies have traditionally classified and certified their products using international standards. Yet, it has been a common practice to find timber in any part of the country without any type of structural certification. Recently, the Ministry of Housing and Urbanism released a norm for the labeling of structural timber. This remediates the lack of information regarding the quality of structural timber, but it is yet unclear how the control and monitoring of that quality is going to be implemented. In Chile, the most used timber species is radiata pine, comprising $97 \%$ of national sawn production [66]. Although the structural quality of this wood is below the average timber of Europe and North America-it classifies as C16 and C24 according to European standards -it has a very rapid growth rate, as the cutting cycle typically lasts only 20 years. Recently, the two major forestry companies of Chile implemented several initiatives for fostering timber construction, including CLT manufacturing and high-tech prefabricated housing plants, which, along with other entrepreneurial initiatives, are expected to increase the availability and quality of wood products and assemblies.

Regarding the release of specific public policies fostering the utilization of timber in construction, there are no special incentives. Nevertheless, it is important to mention that there is a steadily increasing restraint of the energetic performance of the envelopes due to the environmental decontamination plans, and therefore timber construction has becoming increasingly competitive. In addition, the country has a remarkable need to increase industrialization and productivity because the current national construction capacity is unable to cover the housing demand [67]; thus, industrialization is also becoming an important driving agent that is rapidly increasing the interest in timber construction and timber engineering. In the last few years, several governmental organizations have released a few public tenders, in which timber was explicitly requested as the main construction material in an effort to trigger timber construction from the public sector. In addition, dissemination activities have increased in number and attendees in the last few years. The major technical and industrial national event is entitled "Semana de la Madera" (SDLM), 
which attracted more than 22,000 online visitors in 2021 [68]. Apart from the SDLM, the trade fair COMAD has also become an important event in the Chilean wood industry.

\subsection{Spain}

Although Spain has an extensive traditional use of timber in construction, its use was scarce during the 20th century, mainly replaced by concrete. The reference for education is located in the Forestry Engineering School at the Polytechnic University of Madrid, with a long tradition in courses on structural timber. Moreover, their professors published a seminal book on the design of timber structures [69]. Timber education has become a teaching subject, especially in the case of schools of architecture, mainly due to the particular interest of different professors, and remains mainly either as elective subjects or as a complementary part within a broader subject. There were several attempts to create a dedicated Wood Chair at architectural schools, the most recent being that of the University of Navarra, founded in 2011, one of the oldest [70]. There are some postgraduate programs, where a Master in Structural Timber from the University of Santiago is the one with the longest tradition [71]. More recently, master's programs have been created at Universitat Politècnica de València (UPV) and the Institute for Advanced Architecture of Catalonia (IAAC). Regarding the professional timber field, there is a tradition of carpentry diplomas. Recently, specialized diplomas for structural carpenters have been created [72].

Research on timber engineering has been carried out by isolated groups, most of them currently joined in the network Lignomad [73]. Spanish researchers collaborate in the development of European standards, such as Eurocode $5[36,49,63]$, and within different related networking actions, such as COST FP1402 and CA20139 [74,75]. Remarkable in the field of informal education and dissemination is the work done by AITIM, a private association, which has extensively published books and magazines on constructive timber [76]. The reference dissemination event for professionals is Egurtek [77]. Other recent initiatives comprise the series of Lignomad conferences [78] and the Spanish Forum Holzbau [79]. There was no standard of timber structures in Spain until 2007 [80], when it was included in the building technical code (Código Técnico de la Edificación) [81]. Professionals may alternatively use Eurocode 5 [36,63], which was approved in 2004 and is currently under revision, with an expected approval date in 2025 [82]. The actual use of timber in construction is still scarce [83], and mainly used in unfamiliar dwellings. Several particular initiatives of multi-story buildings, mainly related to CLT-based structures, have recently raised attention on timber construction, starting with a pioneering six-story building in Lleida [84]. Other remarkable experiences were a public promotion in Hondarribia (Figure 8) [85] and a private condominium in Barcelona [86]. More recently, a timber building, OUR SHELVES HOUSES, located in Madrid, won the Rebuild award for industrialized construction [87]. Public policies are slowly appearing, with the Region of Navarra being a remarkable example, which enforced the development of nearly-zero-energy houses for public promoted buildings [88] and is actively promoting the design and construction of timber-based buildings through its public agency Nasuvinsa [89]. Figure 8 shows the current development of the multi-story building Zure-Tokia in Pamplona [90]. The neighboring Basque Country region also has an active timber promotion policy, based mainly on the promotion of their local radiata pine.

Spain has the second-largest total forest area in Europe (27.5 million hectares, after Sweden). It doubles the forest area of France, and almost triples that of Germany. However, just $12 \%$ of Spanish forests have a management plan [91], though that figure is slowly increasing. The certification systems used are FSC and PEFC, with PEFC being the most extensive one. However, together they account for only $15.7 \%$ of the total forest area (PEFC, 2,482,656 ha, 13.5\%; FSC, 407,245 ha, 2.21\%) [92]. The most typical use for the extracted timber is pulp (36\%), followed by sawmills $(30 \%)$ and the board industries $(22 \%)$. The industry with the highest share of timber products is bioenergy (33\%) [93]. 


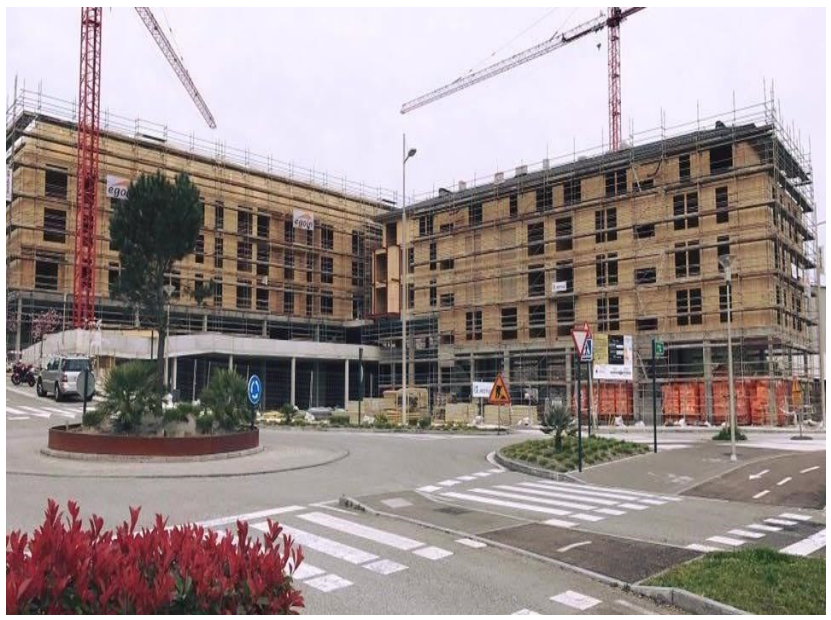

(a)

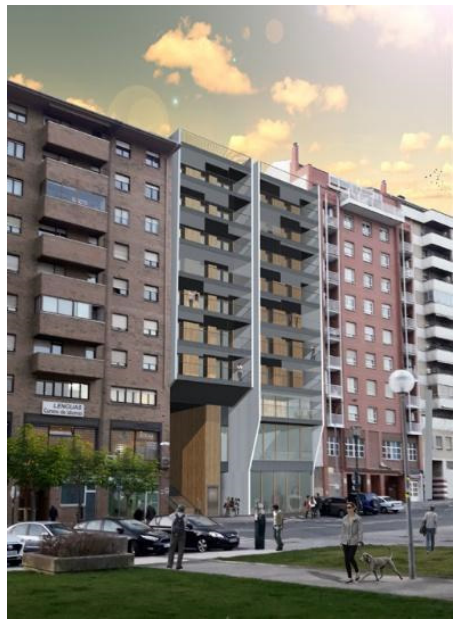

(b)

Figure 8. Some recent iconic timber constructions in Spain: (a) recent timber construction, Hondarribia building; (b) future timber construction, Zure-Tokia building.

\subsection{Guatemala}

The Forestry System of Guatemala revealed that the country has an area of $3,574,244$ hectares covered with forest, which is equivalent to $33 \%$ of the territory. Of the total national forest, $52.7 \%$ is located within the Guatemalan System of Protected Areas. According to Aguilar, there are seven genera of conifers and 17 species of pine in Guatemala [94]. The absence of a standardization of materials and construction methods in wood has limited the promotion of policies oriented toward construction with wood. However, there are policies to encourage forest production, such as the Forest Incentives Program (Programa de Incentivos Forestales-PINFOR), where the species with the greatest potential for construction are included [95]. In Guatemala's engineering and architecture faculties, the potential of wooden structure systems is recognized as a response to the need to project earthquake-resistant buildings. At the level of professional training, there is greater development from the perspective of architecture, and little content in terms of structural design. Technical training exists from the Instituto Técnico de Capacitación y Productividad (INTECAP), but it is aimed at general carpentry and not the construction industry [96]. The few available references are intended for wood-frame structures.

Although wood has been recognized as a construction material for more than 20 years, both structural design and construction are carried out using empirical principles, or concepts of material mechanics that do not reflect the state of the art of wooden structural systems [69]. As of 2018, the Committee for the Promotion of the Use of Wood in Construction was implemented in an effort by various institutions from the public, private, and academic sectors. Among the dissemination activities, a contest and a wood engineering seminar were held in 2019 and 2021, respectively. No demonstration buildings or pavilions have been planned or constructed that promote wood building or expose the state of the art of wood systems. Until 2020, there were no reference standards for construction with wood in Guatemala, and both the structural design and the construction of wood was limited to the designer's criteria. In 2021, the draft standards for classification, characterization, and structural design were concluded as part of an inter-institutional project led by the forestry sector and financed by the Food and Agriculture Organization of the United Nations (FAO). The drafts of the aforementioned standards are being supported by an ongoing test campaign to determine the mechanical properties of three pine species as established by the ASTM D2555 and ASTM D245 standards [97,98], i.e., Pinus oocarpa, Pinus caribaea, and Pinus maximinoi [99]. The draft standards have been submitted to the competent offices, with the goal that the structural design standard be integrated into the Disaster Reduction Standard, and the characterization and classification standards into the Guatemalan Tech- 
nical Standards, where the construction materials are collected. For strategic reasons, the standards developed were oriented toward light-frame construction, although they are not limited to this construction system. Through the Guatemala Green Building Council initiative (GGBC), certifications for sustainable buildings, such as Leadership in Energy and Environmental Design (LEED), Excellence in Design for Greater Efficiencies -(EDGE), and WELL from the International Well Building Institute, are promoted. Likewise, GGBC proposed a voluntary certification aimed at promoting sustainable practices in residential construction-CASA Guatemala [100]. It is expected that these new policies will allow for competitive advantages when using sustainable timber construction.

\subsection{Mexico}

The total plantation forest area occupies $47.7 \%$ of the country's forest area, which is equivalent to 65.7 million hectares, including forest ecosystems with $52 \%$ and jungles with $48 \%$. Unfortunately, this proportion is not reflected favorably in the trade balance, which has historically shown a deficit over the last decade. The forestry sector in the 2013-2017 period reflected a constant average share of $0.24 \%$ according to the national gross domestic product [101]. In proportion, the construction industry with wood products is scarce and there is a dominant presence of micro and small companies dedicated to the transformation of timber forest products, which is reflected in the minimal proportion of academic programs focused on wood science and technology in their curricula, registering the dominance of academic programs with a forestry focus. In 1971, the bachelor's degree program in Wood Technology Engineering was created at the Universidad Michoacana de San Nicolás de Hidalgo, and subsequently, master's and doctorate programs have been promoted in this same field of knowledge, the trajectory of which that has prevailed in their status as accredited quality programs should be highlighted. Unfortunately, despite the available potential of forest area, the volumes of cubic meters for its use, and the existing value chains, this field of professional training has not proliferated except in two educational institutions, the Universidad Sierra Juárez and the Universidad Autónoma Chapingo, where academic content related to timber structures is oriented [102].

There are few companies specializing in the construction of wooden houses, and in Mexico the construction of these is minimal, which may be due to the little information that exists on the subject, since there is a series of questions or myths that make people think that buying or building with wood may represent a challenge to the economy and safety of those who make use of the space. However, there is a relevant use of wood as an architectural and engineering material in various constructions of historic buildings in the country, in which wood has been integrated as an important structural element, as well as in hotels, resorts, restaurants, and cabins or cottages [103]. Regarding the regulations for the use of wood in construction, the released standards address the design and construction of wood structures, qualification and visual classification for structural timber, construction with pine boards and planks, prevention of termite attacks, and the use of coniferous wood piles for bridges, which has been achieved through the participation of various institutions coordinated by the General Directorate of Standards through the National Organization for Standardization and Certification of Construction and Building, S. C. [104]. The National Forestry Commission, the federal institution responsible for promoting sustainable forestry development in the country, points out a certain impediment for housing institutions such as Fovissste, Infonavit, Conavi, and Sedatu to not promote housing built with wood, supposedly because there is an ingrained culture in the country that only rest cabins can be built and the belief that timber is not a real alternative to building housing for everyone, which has a negative impact, although the National Council of Wood in Construction has expressed to the aforementioned federal institutions that they accept its housing proposal. In this sense, CONAFOR itself, as part of its policies towards sustainable forestry development, has established 12 housing design contests with wood as an option to promote public policies on the use of wood in construction $[102,103]$. 


\subsection{Peru}

According to the National Forest and Wildlife Service (SERFOR), Peru has the secondlargest area of the Amazonian Forest globally and the ninth highest cover of forest in general, representing 57\% of the national territory (73 million ha). However, in 2019 the timber industry in Peru contributed just $1.04 \%$ to national GDP [105]. This small percentage is because the demand for wood products only relies on formwork, interior decoration, carpentry elements, and furniture. Programs dedicated to designing new wood structural systems and engineered wood products have not yet been developed in the country. Universities with undergraduate programs in architecture and civil engineering focus on the mechanical properties of timber structural elements based on traditional construction systems such as light-frame and post-and-beam. These standards were established in 1984 by the Andean Project for Technological Development in the Area of Forest Resources (PADT-REFORT). Nevertheless, there are curricula with a forestry approach, where Molina Agrarian University (UNALM) stands out. This university offers undergraduate and postgraduate programs on integral management techniques, transformation, and the use of timber and non-timber forest resources.

The National Census of 2017 revealed that wood is a frequent component of urban and rural dwellings; out of 7,698,900 houses in Peru, 9.5\% used wood on external wall elements and $2 \%$ on their roofs [106]. One of the most common construction systems is prefabricated light-frame structures for basic units. However, one of the main concerns about developing these wood systems is the lack of quality due to the inappropriate use of the material and its relation to poor fire resistance, premature destruction by decay, and provisional nature [107]. In 2015, the Peruvian government launched a new set of regulations aimed at increasing the competitiveness of the timber sector and ensuring the conservation and sustainable production of timber [108]. A case of success in the Peruvian Amazon was the Plan Selva Project (2017) developed by the National Program of Educational Infrastructure (PRONIED) of the Ministry of Education (MINEDU). The goal of this large-scale program was to quickly rehabilitate public schools with a prefab unit system that was easy to install while improving wood construction technology with FSC certification.

In Peru, wood constructed buildings are approved by the Technical Standard E.010 Wood of the National Building Code (RNE). This resource includes structural classification requirements, resistance values, analysis methods, and design and construction processes. Despite the standard's specifications, there are technical and local market gaps related to wood standardization (dimensions, qualities, and humidity condition) [109]. In August 2021, the Ministry of Housing, Construction and Sanitation (MVCS) began a public consultation phase to promote the update of the technical standard. One of the changes consisted of adding several forest species as construction elements, thanks to their excellent structural performance [110]. It is expected that this new standard include requirements designed to ensure safety, innovative new construction techniques, and systems seeking to minimize a building's negative impacts on the environment.

\subsection{Portugal}

Even though about $35 \%$ of the country's surface is covered with forest and the like and the forestry sector contributes to about $5 \%$ of the GDP [111], timber construction and the timber products industry are relatively weak and typically consist of small companies, with the only possible exception being panel production. Mainly for that reason, timber construction was absent, as an autonomous subject, from the curricula of all Portuguese universities and institutes up until the late 1990s. Then, an optative discipline on timber structures was first created at the University of Coimbra, at the MSc level, shortly followed by others, like in University of Minho and some high schools [112]. Globally, the yearly number of attendants must be less than 40 . Nevertheless, there are some ongoing PhD works, mostly framed by wide-range doctoral programs. A doctoral program on timber engineering is set to be created in Coimbra in 2022. 
The Altice Arena Pavilion (see Figure 9), initially known as Utopia, was built for the World Exhibition held in Lisbon in 1998 and was a breakthrough for modern construction with timber in Portugal, which was then unaware of the possibilities of this material and its engineered derivatives. Hundreds of public and private buildings and structures have been built since. Ref. [113] provides a view of timber construction in Portugal, although only through 2011.

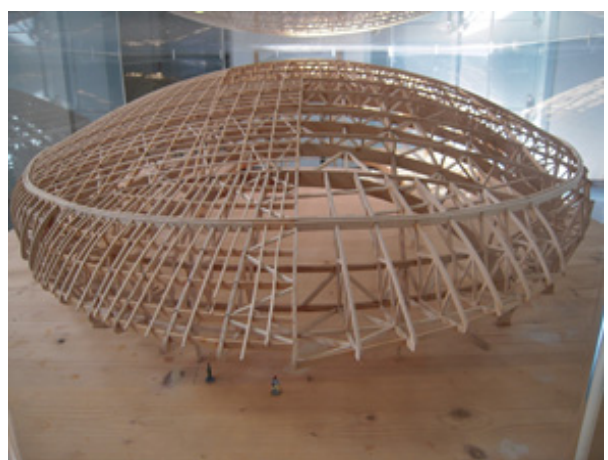

(a)

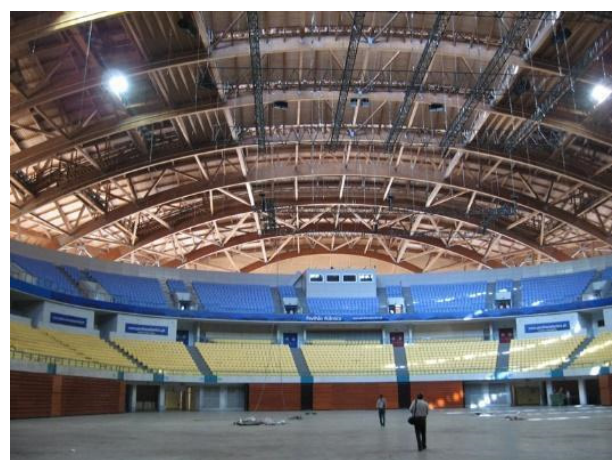

(b)

Figure 9. Example of timber structure in Portugal: (a) Altice Arena (Utopia) structural scale model; (b) Altice Arena, inner view.

The only forest-based strong industry in Portugal is paper and cellulose products and, at a lower level, the cork industry [114]. As a consequence, eucalyptus planting has been increasing in Portugal, while the share of traditional species such as oak, chestnut, and maritime pine progressively lack management or are being affected by fires every summer. To some extent, this is caused by the predominantly private ownership of the forest, together with the low income it provides to the owners and the lack of effective policies to reverse this situation. At the building regulations level, Portugal benefits from belonging to the EEA (European Economic Area) as well as being member of CEN (European Standardization Committee), which means it participates in the elaboration and has access to the vast amount of standards and design codes delivered by this organism, namely Eurocode 5 (timber structures) [36,63,115] and related standards. The Portuguese institution in charge of standardization issues is IPQ (Instituto Português de Qualidade), which hosts or supervises the mirror national committees of those of CEN [116].

\subsection{Uruguay}

Uruguay has no tradition in timber construction. Cultural roots, misconceptions of stakeholders concerning the use of wood in construction, wind, and fire risk perceptions by professionals and end users are the main reasons that prevent the massive adoption of timber as a structural material. In recent years, two main factors have been gradually changing this situation; the first is related to construction costs and execution times, and the second to the availability of timber and engineered wood products (EWP) in the domestic market. The planted forest area has significantly increased in the last 30 years, today reaching approximately 1 million hectares of fast-growing species, mostly pine and eucalyptus [117]. Uruguay is one of the few countries where its entire wood-processing industry relies on renewable plantations, of which more than $90 \%$ include certified forestry practices [118]. In 2019, solid timber, mainly from pine, was the country's seventh most exported product [119]. In the national market, consumption of structural timber is marginal, yet a minimum of 2 million cubic meters of pine wood are annually available and ready to process for construction purposes [120]. In this context, a novel cross-laminated timber (CLT) and glulam (GLT) plant is under construction and the opening is scheduled for the end of 2022. The CLT plant will be the largest and most advanced in South America and is expected to produce $70,000 \mathrm{~m}^{3}$ /year of mass timber [121]. A plywood manufacturing com- 
pany and several sawn mills and preservative treatment plants provide products mostly for timber-frame houses. Generally, lumber is commercialized with no technical specifications.

Until recently, the Uruguayan standard corpus for structural timber was negligible. The technical standards were written by specialized committees in the Uruguayan Institute of Standardization (UNIT), and unless otherwise specified, their application was voluntary. In 2017, the first Committee focused on structural timber was established, and since 2018 a set of standards including visual grading rules for sawn timber [122,123] and manufacturing requirements for GLT $[124,125]$ were approved. Technical reports grounded in extensive research by universities and laboratories provided the background information to the UNIT Committee. Currently, the convenience of adopting Eurocode 5 and the drafting of the national annexes is being discussed. With the approval of the two visual grading rules, some mills began to deliver graded timber to the domestic market, but this is still incipient. At the same time, several buildings involving small, medium, and large structures are being constructed with timber and EWP around the country. One iconic example expected to be complete in January 2022 is the Museum of American Contemporary Art (See Figure 10), a complex spatial structure of long-span glulam beams and columns with double curvature and variable sections. Another example is the José Ignacio Hostel, built in 2017, which was the first CLT construction in the country. The hostel comprises five buildings, developed in two and three stories.

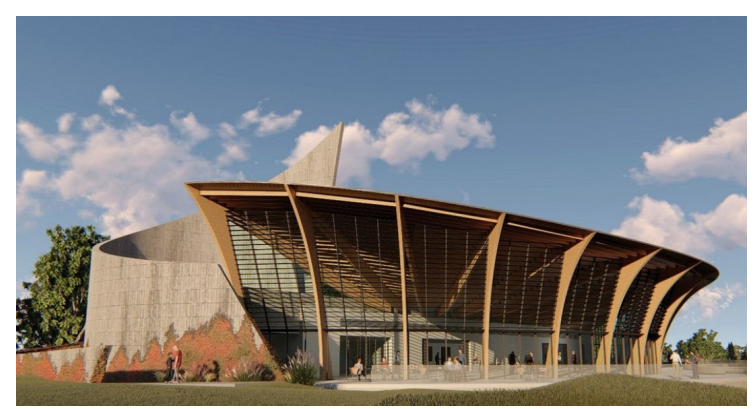

(a)

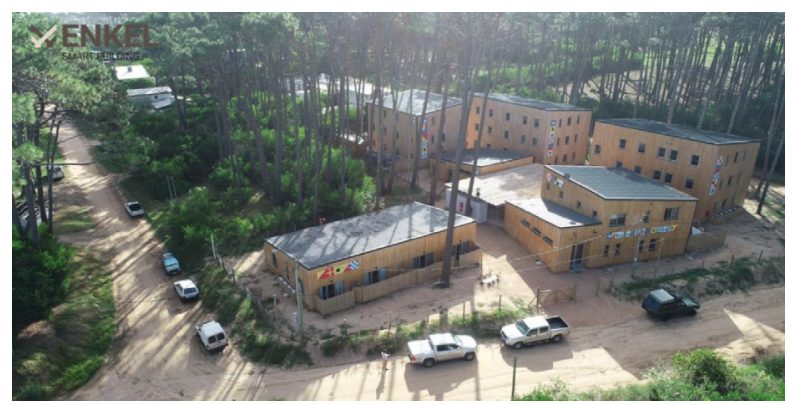

(b)

Figure 10. Examples of timber structures in Uruguay: (a) Museum of American Contemporary Art; (b) José Ignacio Hostel.

Education in the design and construction of timber structures used to play a minor role in the various Uruguayan architecture and civil engineering programs. In 2018, the first postgraduate program, a diploma in Timber Structural Design and Construction jointly taught by the Faculty of Architecture of Universidad ORT Uruguay and the Faculty of Engineering of Universidad de la República, was launched. The novelty of this diploma was the interaction between students with two different backgrounds who were encouraged to work together, something that had rarely happened before in Uruguay. In addition, an undergraduate course devoted to structural design with timber was included in the civil engineering curricula. In November 2019, Uruguay hosted, for the first time, an international conference exclusively devoted to timber construction, the fourth edition of the Latin American Conference of Timber Structures (CLEM). With more than 200 attendees from Latin American and Europe, CLEM 2019 contributed in the efforts to disseminate the state of the art of timber construction [126]. Other dissemination activities involved the presentation of two innovative prototypes, La Casa Uruguaya (See Figure 11), winner of the 2017 national energy efficiency prize and the first-place prize at the international Solar Decathlon 2015, and a vehicular timber bridge in Las Brujas, made of glulam and a CLT deck and constructed in 2016. Similar to other South American countries, there have been public policies fostering timber construction in Uruguay. However, few actions and initiatives by the government and congress have been undertaken. In December 2020, the Honorary Committee on Wood was approved by law, aiming at promoting the use of local wood for construction and furniture. 


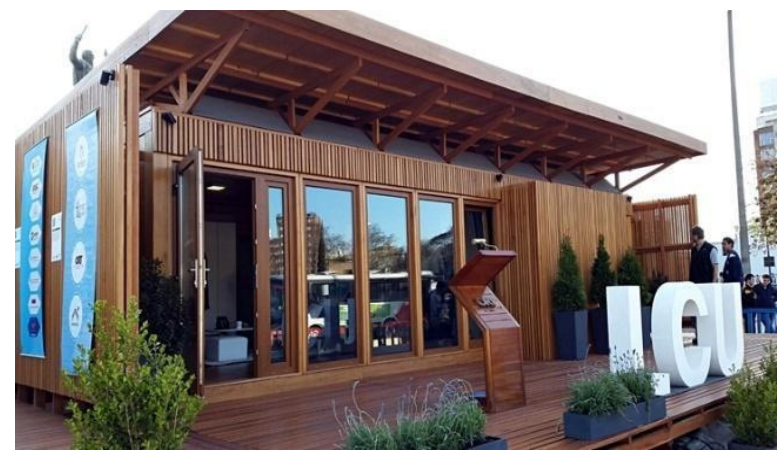

(a)

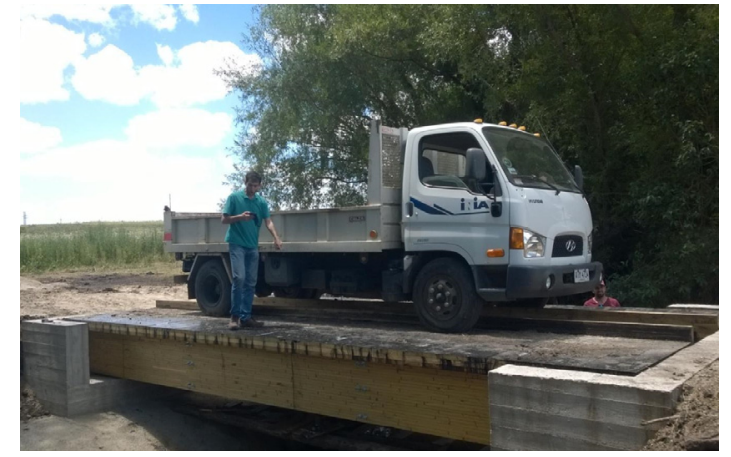

(b)

Figure 11. Prototype timber structures: (a) La Casa Uruguaya; (b) vehicular timber bridge, Las Brujas.

\section{Perception Surveys}

\subsection{Global Analysis}

A survey was conducted to determine the perception of sustainable timber construction by professionals and potential users in the Ibero-American region. This survey was answered by 233 construction professionals in 15 countries (see a depiction by country in Figure 12), among which $42.7 \%$ corresponded to architects, $44.9 \%$ to engineers, $4.7 \%$ to builders, and $7.7 \%$ to other technical-professional careers associated with the construction industry. Regarding the age range of the respondents, $75.1 \%$ were between 18 and 37 years old, 17.2\% were between 38 and 51 years old, and $7.7 \%$ were over 52 years old.

\begin{tabular}{lcc} 
Argentina & 26 & $11.2 \%$ \\
Brazil & 1 & $0.4 \%$ \\
Colombia & 23 & $9.9 \%$ \\
Costa Rica & 29 & $12.4 \%$ \\
Chile & 14 & $6.0 \%$ \\
Ecuador & 3 & $1.3 \%$ \\
El Salvador & 1 & $0.4 \%$ \\
Spain & 11 & $4.7 \%$ \\
Guatemala & 24 & $10.3 \%$ \\
Mexico & 1 & $0.4 \%$ \\
Panama & 1 & $0.4 \%$ \\
Paraguay & 1 & $0.4 \%$ \\
Peru & 71 & $30.5 \%$ \\
Portugal & 10 & $4.3 \%$ \\
Uruguay & 17 & $7.3 \%$ \\
\hline Total survey & 233 & $100 \%$
\end{tabular}

(a)

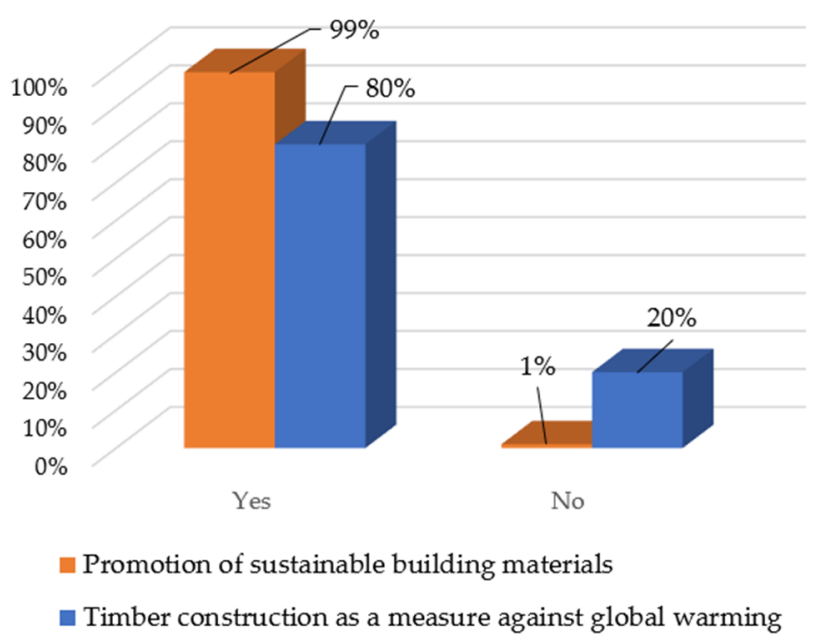

(b)

Figure 12. Total surveys: (a) surveys per country; (b) perception of material sustainability.

From the survey results, almost all respondents $(98.5 \%)$ agreed that it is necessary to promote the use of more sustainable building materials than those traditionally used. Furthermore, $79.9 \%$ considered that the use of wood as a sustainable material would also be a measure to counteract climate change due to global warming. These results are based on the users' responses, which were subsequently contrasted with the results of the benefits of using wood in substitution of materials such as concrete and masonry due to the sustainability in the manufacturing process of the material when this is carried out through sustainable forest management.

Regarding the use of the material, $53.2 \%$ of the respondents stated that they had basic knowledge of the use of timber in construction, whereas $33.1 \%$ had intermediate knowledge and the other $13.7 \%$ had advanced knowledge. Of the total number of respondents who indicated a basic level in the use of wood, $62.3 \%$ corresponded to people between 18 and 
37 years of age, $27.5 \%$ to people between 38 and 51 years of age, and $22.2 \%$ to people over 52 years of age. The knowledge was partly associated with the use of wood in their professional practice, since $28.6 \%$ of the total number of respondents had used the material for some structural purpose, such as beams, columns, and light-frame, or laminated elements, among others; $26.5 \%$ of the total had used timber in the manufacturing of furniture, $16.7 \%$ had used timber only in finishes, and $44.9 \%$ had not used it in their projects at all.

About the perception of its use in construction, of the total number of respondents, $47.4 \%$ expressed a preference for wood for the acquisition of their own personal dwelling, $47.9 \%$ preferred reinforced concrete, and $35.1 \%$ preferred masonry. These results varied when asking about the acquisition of an apartment in a high-rise building, as $30.8 \%$ expressed a preference for wood, $57.3 \%$ preferred reinforced concrete, and $25.2 \%$ preferred masonry. Figure 13 shows the results regarding the perception of the main advantages of wood construction. The results reveal that the three most valuable attributes of timber construction included the visual attractiveness, reduced construction times, and its being a renewable resource, with $71 \%, 66 \%$, and $52 \%$ preference, respectively. Conversely, the results of the main disadvantageous attributes of wood construction are shown in Figure 14. Here it can be identified that for the total number of respondents, the three most relevant drawbacks of timber construction were the vulnerability to biotic agents (termites, fungi, etc.), lack of regulations, and fire resistance, with 49\%, 34\%, and 33\% preference, respectively.

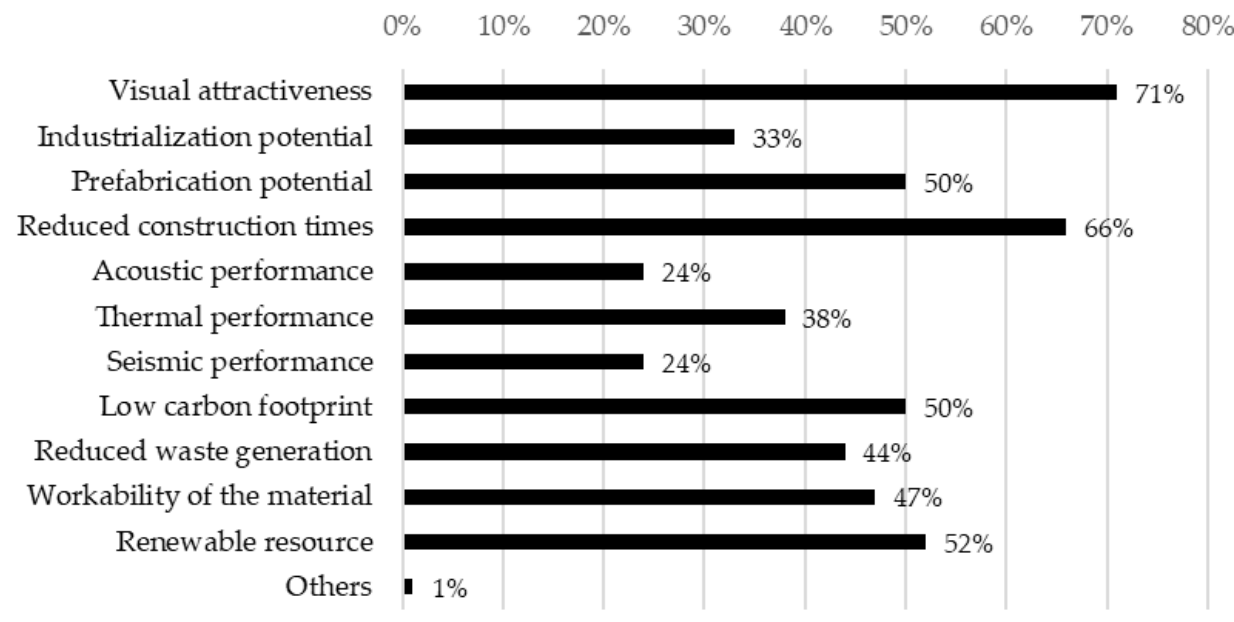

Figure 13. Results of the perception of attributes that benefit wood construction.

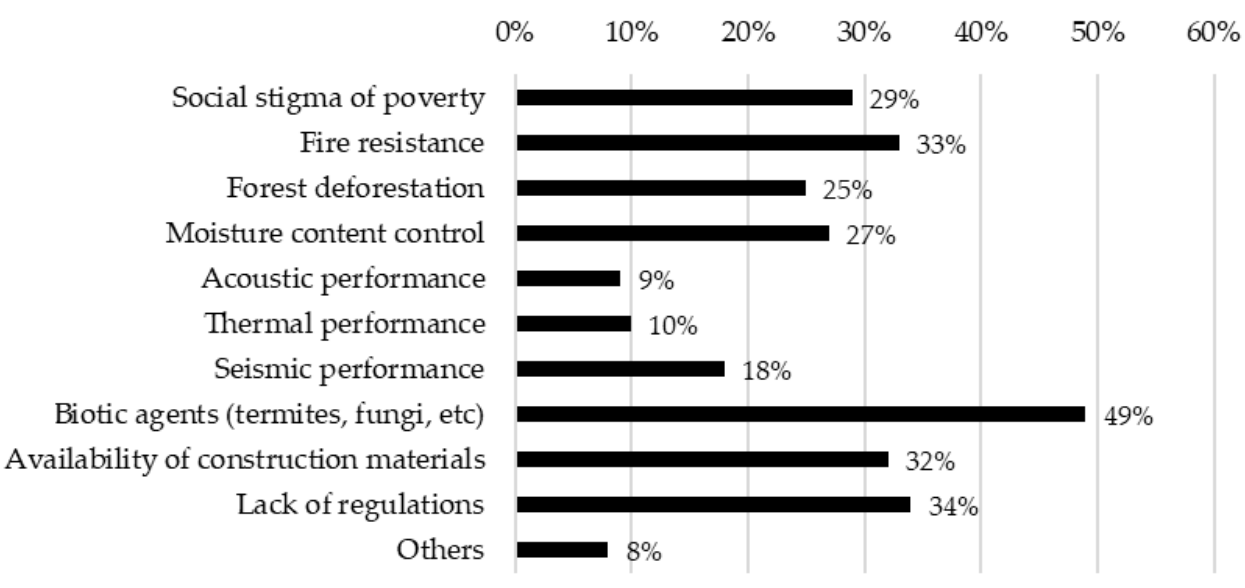

Figure 14. Results of the perception of attributes that hinder wood construction. 
In terms of the interest of the respondents in professional training, Figure 15 shows the main topics of interest indicated by the respondents, where the three most demanded fields to be included in education were the possible building/component solutions (timer flooring systems, perimetral walls, divisory walls, roofs and ceilings, etc.), structural design, and seismic design, with a total preference by the respondents of $68 \%, 63 \%$, and $58 \%$, respectively. As for the preferred channels of knowledge acquisition, these are summarized in Figure 16, where the format preferences for these channels included 62.7\% of respondents preferring face-to-face, 39.5\% preferring an asynchronous online format, and $37.7 \%$ preferring a synchronous online format.

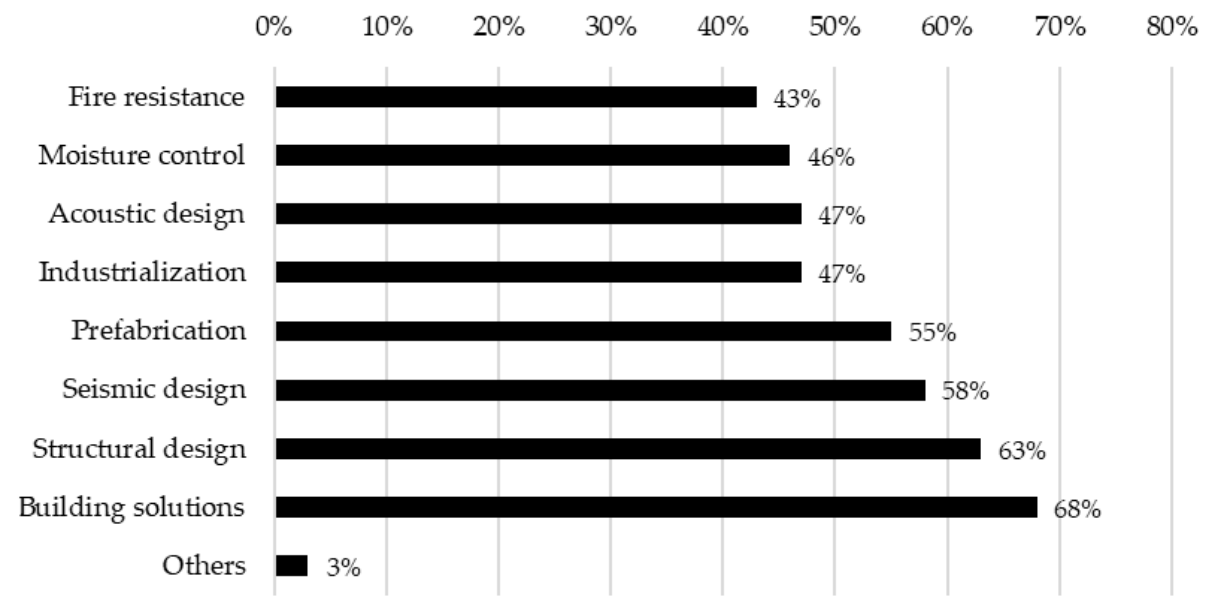

Figure 15. Results of the perception of the main training topics.

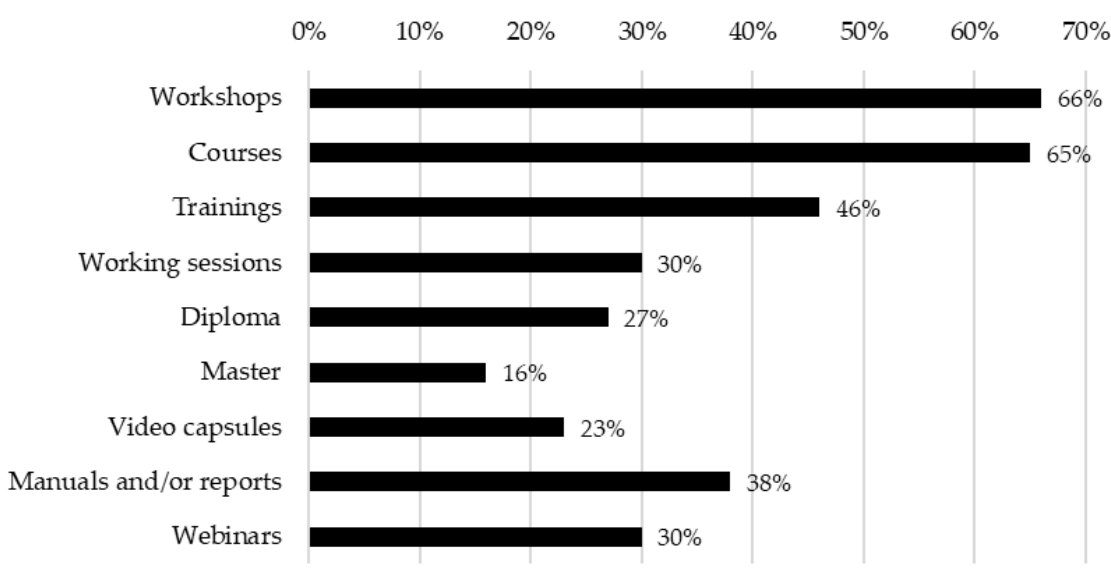

Figure 16. Results of the perception of the main channels of knowledge acquisition.

From the results of the survey, it is possible to appreciate that in terms of attributes that benefit wood construction, along with the visual attractiveness of the material, aspects related to sustainable construction, such as low carbon footprint, low waste generation in construction, and the use of renewable materials, were favored to a greater extent. This also corresponds to the users' perception of the need to promote the use of more sustainable construction materials, in view of the implementation of eco-friendly government programs and public policies around the region.

On the other hand, it is possible to identify two major issues regarding the attributes that hinder the development of wood construction. The first is associated with the constructive feasibility of wood structures in the region, reflected in the availability of the material and the lack of construction and design regulations. Acoustic, thermal, and seismic performance do not represent a barrier for most users. It is also possible to identify a topic associated more with the cultural use of wood and lack of knowledge on how to manage 
the durability of the material, reflected in the social stigma of poverty, fire resistance, and susceptibility to biotic agents. Regarding the sustainable management of the resource, reflected in the results of forest deforestation, a quarter of the respondents stated that this would be an impediment to the development of wood construction.

\subsection{Regional Group Analysis}

A comparison of the general results of perception and professional training in the region with the results of groups $\mathrm{A}, \mathrm{B}$, and $\mathrm{C}$ was made. Figure 17 shows the comparison of the overall results on the perception of attributes that benefit wood construction for all groups. Although the general trends observed in the region as a whole were similar in the different groups studied, there were some changes: Visual attractiveness was more important for groups A and B, with $85.7 \%$ and $79.3 \%$, respectively, but it dropped considerably for group B, reaching only $49.3 \%$. Regarding the reduction in construction time, this continued to be among the top three attributes for users of all groups, registering percentages of $66.7 \%, 73.1 \%$, and $63.5 \%$ for groups A, B, and C, respectively. The renewable characteristic of the material continued to be important for groups $\mathrm{A}$ and $\mathrm{B}$, with $66.7 \%$ and $62.7 \%$, respectively, but it dropped in group B to $44.8 \%$. Individually, some important aspects are as follows: In group A, the trends observed in the region overall were preserved. For group $B$, the prefabrication potential and the low carbon footprint gained importance, both with $62.3 \%$. For group C, the material's workability was important, with $47.6 \%$. Conversely, Figure 18 shows the comparison of the overall results of the perception of attributes that hinder wood construction. The results show that part of the general trends observed in the region as a whole were maintained in the different groups studied, but there were some considerable changes between the different regions: Damage by biotic agents (termites, fungi, etc.) remained one of the main categories of importance for groups A, B, and C, with percentages of $47.6 \%, 53.7 \%$, and $46.9 \%$, respectively. Regarding fire resistance, it remained an important factor for groups A and C, with $28.6 \%$ and $36.6 \%$, respectively, but it dropped in group $B$, reaching only $28.4 \%$. Regarding the lack of regulations and design standards, this only maintained its importance in group B, with $46.3 \%$, and it dropped in groups $A$ and C, reaching values of $9.5 \%$ and $32.4 \%$, respectively. Individually, some important aspects are as follows: For group A, the social stigma of poverty and the availability of materials gained importance, with $28.6 \%$ and $38.1 \%$, respectively. For group $B$, the social stigma of poverty became important, with $35.8 \%$. For group C, control of moisture content was important, with $35.2 \%$.

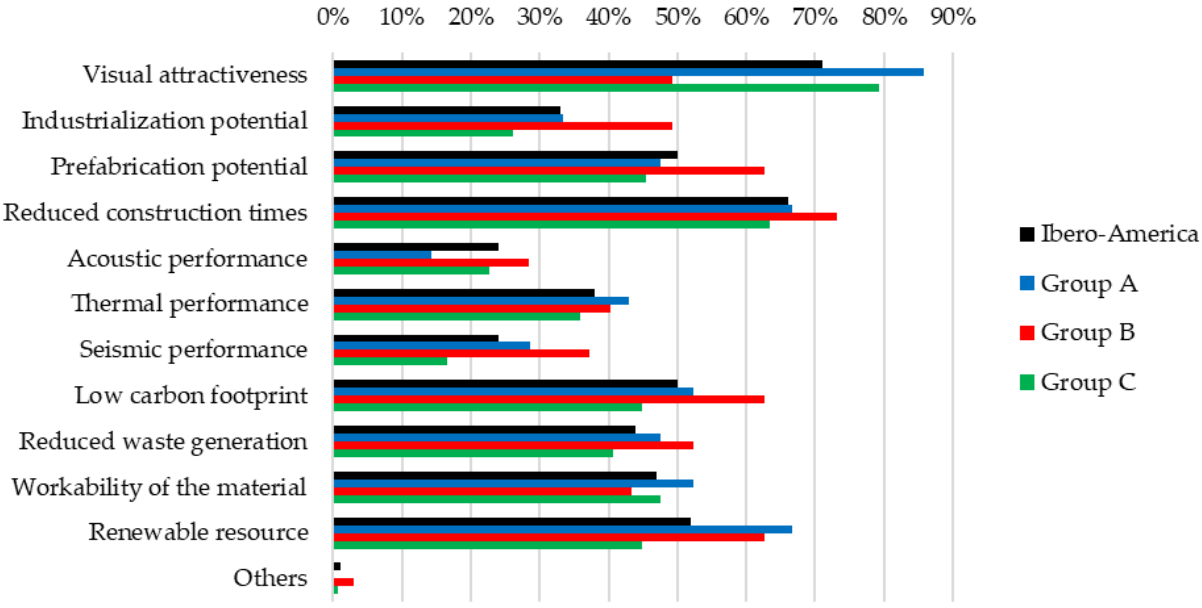

Figure 17. Comparison of the overall results of the perception of attributes that benefit wood construction for groups A, B, and C. 


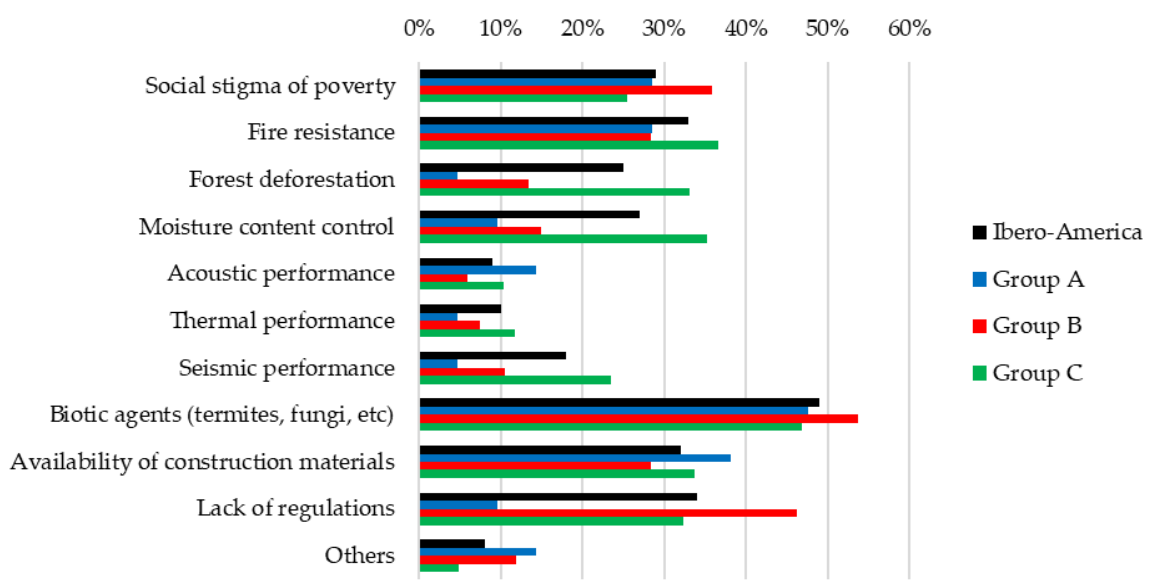

Figure 18. Comparison of the overall results of the perception of attributes that hinder wood construction for groups A, B, and C.

In terms of the interest of the respondents in professional training, Figure 19 shows the comparison of the overall results of the perception of the main training topics. The results show that the general trends observed for the region as a whole were maintained in the different groups studied, with some minor changes among the different regions: The importance of constructive solutions remained one of the main categories of importance for groups A, B, and C, with percentages of $76.2 \%, 64.2 \%$, and $68.3 \%$, respectively. Similarly, the importance of structural calculations remained one of the main categories of importance for groups A, B, and C, with percentages of $57.1 \%, 50.8 \%$, and $69.0 \%$, respectively. Regarding seismic design, this remained an important factor for group $C$, with $71.0 \%$, but it decreased in groups $\mathrm{A}$ and $\mathrm{B}$, with $38.1 \%$ and $35.8 \%$, respectively. Individually, some important aspects are as follows: For group A, fire resistance gained importance, with $42.9 \%$. For group B, prefabrication was important, with $56.7 \%$. For group $\mathrm{C}$, the trends of the region as a whole were maintained. In addition, the results of the preferred channels for knowledge acquisition in the different groups are presented in Figure 20.

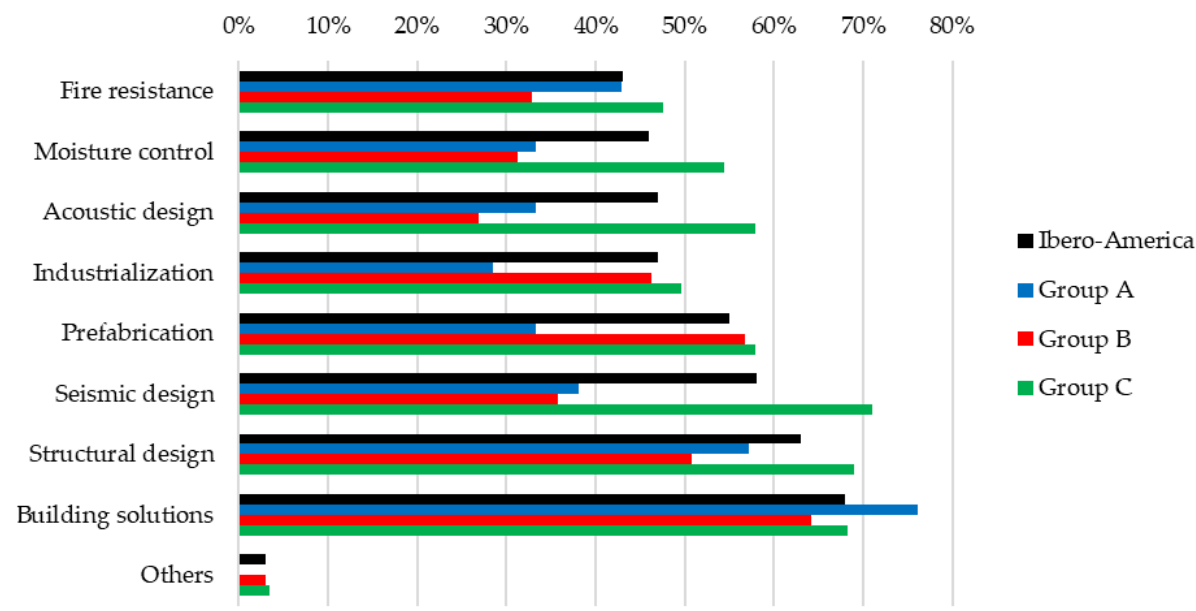

Figure 19. Comparison of the overall results of the perception of the main training topics for groups A, B, and C. 


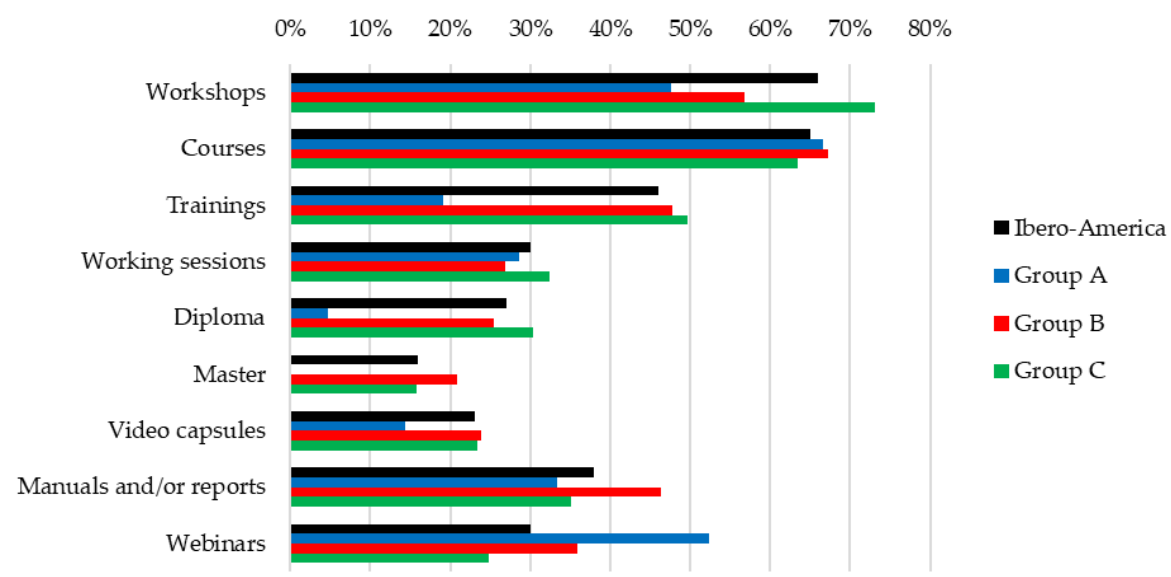

Figure 20. Comparison of the overall results of the perception of the main channels for knowledge acquisition for groups $\mathrm{A}, \mathrm{B}$, and $\mathrm{C}$.

\section{Discussion}

The national analyses of the different countries of Ibero-America show that the development of the timber industry is greater in countries that have implemented strategies that not only target the construction sector itself, but also the forestry sector and intermediate sectors of the wood product value chain. The aim in those countries has been to manage the forest resource in a sustainable manner through the correct management of forests by means of international certifications. The need to classify and characterize wood as a construction material is a common element in most of the countries studied, where most of them have focused their efforts on the development of regulations to ensure its use in construction. At the same time, the calculation and structural design methodologies are commonly based on European or North American references, adapted to the predominant forest species of each area.

The elaboration of iconic timber constructions has been a common factor in countries with a more developed wood construction industry, such as Portugal, Spain, Brazil, Costa Rica, Chile, and Uruguay. Although the level of development of wood construction is quite heterogeneous throughout the Ibero-American region, this has not been an impediment to promoting international collaboration. Over the last two decades, various activities have been carried out to establish international relations between academics and industry professionals in order to promote different sectors of the industry associated with wood. International events include CLEM (Congreso Latinoamericano de Estructuras de Madera), a Latin American congress involving the participation of academics, professionals, and technicians together with companies from the forestry, wood, and construction sectors. Currently, this congress has held four editions, with the first one held in Concepción (Chile, 2009), the second one in Junín (Argentina, 2017), the third one in San Carlos (Brazil, 2018), and the most recent edition in Montevideo (Uruguay, 2019). The fifth edition of the congress is expected to be held in Colombia. Its activities include lectures and technical talks by international speakers, technical visits to wood construction sites, and social gatherings [126].

At the Ibero-American level, CIMAD (Congreso Ibero-Latinoamericano de la Madera en la Construcción) has been consolidated as the main international instance of wood construction within the Ibero-American region [127]. The first version of this event was held at the University of Coimbra (Portugal, 2011), gathering a total of 280 participants from 14 countries. Subsequently, a second edition was held in Junín (Argentina, 2017) in conjunction with the second version of CLEM, this time including 278 participants from 14 countries. The third edition is expected to be held in Madrid in the year 2024, covering similar topics to those of previous years: genetics and forest improvement, production of wood for construction, wood characterization, wood industrialization, wood structures, wood architecture, durability and preservation of wood, and restoration of wood structures. 
In terms of networking, the RIDICM Network (Red para industrialización y digitalización de la industria de la construcción en madera) has recently been consolidated to promote the industrialized use of wood at the Ibero-American level [128]. With this, it seeks to generate channels and linkages between research entities and the business world, focused on small and medium enterprises, to meet the needs of construction, increasing capacities in the productive sector of industrialization with wood in a sustainable way. Currently, the network is made up of 12 Latin American countries, with more than 30 participants.

Among the factors that hinder the development of a sustainable construction industry, a common factor throughout the Ibero-American region is the difficulty of finding certified wood for use in construction. This is also reflected in the results of the perception survey, where $32 \%$ of the respondents referred negatively to the availability of the material. In this way, a vicious circle is generated in the construction industry in Latin American countries with little or no wood construction tradition, since not having the necessary raw material for the elaboration of constructions, due to the lack of certification processes or low quality control to certify its structural use, does not promote its use in construction, which generates two effects: The material is not available for construction, and the training of construction professionals with wood expertise is not promoted.

A key factor in countries with a more developed wood construction industry has been the promotion of professional wood-training programs. At the Latin American level, it is possible to find educational programs at the undergraduate and postgraduate levels, distinguishing courses, workshops, diploma courses and master's degrees in most of the countries studied. However, doctoral training programs have been scarce in the region. Given the lack of wood construction tradition in the region, it is still at an early stage compared to European or North American wood construction, where it is strongly complemented by the industrialization of its construction processes. It would be crucial for those regions with less development in wood, together with those that are emerging, to incorporate industrialized or prefabricated construction concepts into wood construction, allowing them to be part of the early stages of wood construction design. This would allow them to boost the wood construction industry in an industrialized way from the beginning, giving way to a construction philosophy focused on the use of technologies that not only make use of renewable and less polluting construction materials, but also fewer time costs in the different construction stages, enabling an increase in housing production and partially solving the housing deficit in each of the regions.

In the survey results, although there were themes that are transversal to the entire Ibero-America region, there were some particularities based on the areas of the region and the users themselves. Regarding the users of wood construction, in general, most of those who had a basic understanding of the material were between 18 and 37 years old, which corresponds to a user profile in professional training or a graduate with sufficient experience to carry out projects with wood. Likewise, this user profile is more focused on contemporary environmental issues, promoting the use of sustainable materials.

Regarding the transversal themes of the region, there were factors of common interest, such as resistance to fire and biotic agents, together with the need for training in structural calculation and development of construction solutions. However, there were particularities specific to each region that correspond to the state of development of timber construction in the different countries that make up the region. An example of this is the case of group A, composed of Spain and Portugal, with respect to the lack of regulations and standards, where it reached only $9.5 \%$ of interest for users, whereas in regions B and C, corresponding to Latin American countries, this factor was of over 30\% importance for users $(46.3 \%$ and $32.4 \%$, respectively). This corresponds to the state of the art in terms of regulations in Latin America, where overall progress is less than in European countries. However, this situation is reversed when we talk about the availability of the material, given that for the European group $\mathrm{A}$, this factor was $38.1 \%$ important to its users, ranking it as one of the three main factors for the group, whereas for the Latin American groups B and C it reached $28.4 \%$ and $33.8 \%$, respectively. 


\section{Conclusions and Outlook}

This article presented an overview of the state of the art on the current development of wood construction in different Ibero-American countries, covering the status of educational programs, demonstration buildings, public policies, and construction standards. The conclusions described below are derived from the analysis carried out both at the IberoAmerican regional level and individually for each country, among which it is mainly identified that:

- There are different levels of development in timber construction in the Ibero-American region, where, with the exception of some regions with a timber construction tradition, the general trend in Ibero-America shows an industry in development.

- The development of the timber construction industry is directly associated with the sustainable management of forest resources in each region, mainly native forests and areas destined for plantations. This in turn conditions the obtaining of raw material for the industry, facilitating the identification of the product from its origin and with it the processes of certification, classification, and characterization of the material for its use in the construction industry. Indeed, the availability of equipment is an important factor for European users, whereas for Latin American users it lags behind the lack of regulations.

- In regions with little wood construction tradition, public policies and the lack of construction and design regulations are often the main obstacles to the development of wood construction. This is reinforced from the user's point of view, given that in countries with developed timber industries (mainly European or those with European influence) there is no perception that there is a lack of regulations to develop timber constructions. In addition, there is a lack of demonstrative buildings that certify construction experience with the material.

- There is a lack of training programs in wood construction, since higher education institutions do not include specific wood construction courses in their programs. In addition, there is a lack of postgraduate specialization programs to generate regional experts with the necessary knowledge to promote the development of each region. The need for training in structural calculation and construction solutions is transversal to the entire Ibero-American region, whereas topics such as fire, earthquakes, and prefabrication design are important, but only at the local level.

There are many similarities among the countries of the region in terms of the impediments to the development of wood construction, which are mostly associated with regulatory, cultural, and material availability issues. It is necessary to make progress in these three areas in order to have a solid foundation for the development of wood construction in the region.

In order to promote not only the development of the timber construction industry in the region, but also to generate a sustainable management of the resource, it is necessary to promote measures in countries with less developed industries that allow the forest resource to be treated from a sustainable point of view, for which some strategies and next steps are presented:

- Promote public policies on forest management so that regions with forest potential can manage their resources in a sustainable manner from an early stage.

- Develop regulations that are specifically adapted to the needs and availability of resources in each country of the region. Alternatively, implement pre-existing foreign regulations adapted to the country.

- Break down the cultural barrier of the use of wood as a precarious construction material associated with poverty. It is necessary to educate citizens and construction professionals through educational programs and the construction of demonstration buildings in wood so that users can interact with it.

- Promote a construction industry with an industrializable approach, which in the long term could be an answer to the housing deficit in the region, provided that the cultural 
barriers that prevent the development of the timber industry are overcome, as well as the procurement of forest resources for construction in each country.

- According to the channel's preferences for knowledge acquisition, it would be advisable to promote transversal training plans, mainly in structural calculation and the development of construction solutions, in each Ibero-American location, which could be complemented with online programs at the local level or in other collaborating Ibero-American regions.

Author Contributions: Conceptualization, R.A., P.G., A.G., Â.d.V., M.d.P.D., G.G., J.M.C., E.D.L., F.C., C.G., J.N., and L.M.; formal analysis, R.A.; data curation, R.A.; writing-original draft preparation, R.A., P.G., A.G., Â.d.V., M.d.P.D., G.G., J.M.C., E.D.L., F.C., C.G., J.N., and L.M.; writing-review and editing, R.A., P.G., and J.M.C.; visualization, R.A.; supervision, R.A., and P.G.; project administration, R.A.; funding acquisition, P.G. All authors have read and agreed to the published version of the manuscript.

Funding: This research was funded by RIDICM, Network for the Industrialization and Digitalization of the Wood Construction Industry, grant number 321RT0114.

Institutional Review Board Statement: Not applicable.

Informed Consent Statement: Not applicable.

Data Availability Statement: The data presented in this study are available on request from the corresponding author. The data are not publicly available because they correspond to the internal database of the Network for the Industrialization and Digitalization of the Wood Construction Industry.

Acknowledgments: The authors acknowledge the support of RIDICM. The authors also acknowledge the support of ANID BASAL FB210015 CENAMAD and UC Center for Wood Innovation (CIM UC), Felipe Icimoto of AMATA S.A., and Adrián Eiras of Cadwork Ibérica \& Latinoamérica for sharing their database for the perception survey presented in the study.

Conflicts of Interest: The authors declare no conflict of interest.

\section{References}

1. United States Census Bureau. U.S. and World Population Clock. Available online: https://www.census.gov/popclock/world (accessed on 30 October 2021).

2. The World Bank. GDP (current US\$). Available online: https:// data.worldbank.org/indicator/NY.GDP.MKTP.CD (accessed on 30 October 2021).

3. Food and Agriculture Organization of the United Nations (FAO). Global Forest Resources Assessment 2020: Main Report; FAO: Rome, Italy, 2020.

4. UNESCO. Churches of Chiloé. Available online: https://whc.unesco.org/en/list/971/ (accessed on 30 October 2021).

5. Moore, J. Growing fit-for-purpose structural timber. What is the target and how do we get there? N. Zeel. J. Forest. 2012, 57, 17-24.

6. Guindos, P. Conceptos Avanzados del Diseño y la Construcción con Madera. Parte II: CLT, Modelación Numérica, Diseño Anti-incendios y Ayudas al Cálculo; Ediciones UC: Santiago de Chile, Chile, 2019. (In Spanish)

7. Guindos, P. Fundamentos del Diseño y la Construcción con Madera; Ediciones UC: Santiago de Chile, Chile, 2019. (In Spanish)

8. Churkina, G.; Organschi, A.; Reyer, C.P.O.; Ruff, A.; Vinke, K.; Liu, Z.; Reck, B.K.; Graedel, T.E.; Schellnhuber, H.J. Buildings as a global carbon sink. Nat. Sustain. 2020, 3, 269-276. [CrossRef]

9. Bedon, C.; Mattei, S. Facial Expression-Based Experimental Analysis of Human Reactions and Psychological Comfort on Glass Structures in Buildings. Buildings 2021, 11, 204. [CrossRef]

10. World Resources Institute. 6 Barriers to Protecting and Restoring Forests—and Strategies to Overcome Them. Available online: https: / www.wri.org/insights / 6-barriers-protecting-and-restoring-forests-and-strategies-overcome-them (accessed on 30 October 2021).

11. Brack, D. Sustainable Consumption and Production of Forest Products. United Nations Forum on Forests. 2018. Available online: https://www.un.org/esa/forests/wp-content/uploads/2018/04/UNFF13_BkgdStudy_ForestsSCP.pdf (accessed on 28 October 2021).

12. Cossalter, C.; Pye-Smith, C. Fast-Wood Forestry: Myths E Realities; Center for International Forestry Research: Jawa Barat, Indonesia, 2003.

13. Food and Agriculture Organization of the United Nations (FAO). Association of Regional Autonomous Corporations and Sustainable Development-Asocars Bogotá, Colombia; FAO: Rome, Italy, 2021.

14. Gobierno de España. Ministerio Para la Transición Ecológica y el Reto Demográfico. Estadísticas. España. Available online: https:/ / www.miteco.gob.es/es/biodiversidad/estadisticas/ (accessed on 18 November 2021). 
15. Sistema de Información Forestal de Guatemala (SIFGUA). Comercio Interno de Productos Forestales. Guatemala. Available online: http:/ / www.sifgua.org.gt/ComericioInterno.aspx (accessed on 18 November 2021).

16. Portuguese Institute of Quality. Norma Portuguesa NP 4305; Portuguese Institute of Quality: Lisbon, Portugal, 1995.

17. Portuguese Institute of Quality. Norma Portuguesa NP 4544; Portuguese Institute of Quality: Lisbon, Portugal, 2015.

18. Oficina de Planeamiento y Presupuesto. Oportunidades para el Futuro de la Bioeconomía Forestal en Uruguay. Uruguay. 2019. Available online: https://www.opp.gub.uy/sites/default/files/inline-files/Oportunidades\%20para\%20el\%20futuro\%20de\% 201a\%20bioeconomi\%CC\%81a\%20forestal\%20en\%20Uruguay.pdf (accessed on 18 November 2021).

19. Bokkestijn, A.; López Ortiz, M.; Moscoso, J. Estudio del Mercado Nacional de Madera y Productos de Madera para el Sector de la Construcción; SNV-CITEmadera: Lima, Perú, 2009; Available online: https:/ / www.gob.pe/institucion/citemadera/informespublicaciones / 1359823-estudio-del-mercado-nacional-de-madera-y-productos-de-madera-para-el-sector-de-la-construccion (accessed on 18 November 2021).

20. Instituto Nacional de Normalización (INN). NCh1198:2014 Madera-Construcciones en Madera; INN: Cálculo, Chile, 2014.

21. ONF ANDINA. Pacto Intersectorial por la Madera Legal en Colombia, Estudio de Estimación y Caracterización del Consumo de Madera en los Sectores de Vivienda y Grandes Obras de Infraestructura; Ministerio del Medio Ambiente y Desarrollo Sostenible: Bogotá, Colombia, 2016.

22. Instituto Nacional de Estadísticas Guatemala. Censo Población y Vivienda. Available online: https://www.censopoblacion.gt/ (accessed on 18 November 2021).

23. Ministerio de Vivienda y Urbanismo (MINVU). Estadísticas Habitacionales. Chile. 2018. Available online: https://www. observatoriourbano.cl/estadisticas-habitacionales/ (accessed on 18 November 2021).

24. SENASA. Bosques Argentinos, Actividad Forestal y Economías Regionales. Buenos Aires. Argentina. 2021. Available online: http:/ / www.senasa.gob.ar/senasa-comunica/noticias/bosques-argentinos-actividad-forestal-y-economias-regionales (accessed on 20 November 2021).

25. Argentina: Plantaciones Forestales y Gestión Sostenible. Dirección de Producción Forestal. Ministerio de Agricultura, Ganadería y Pesca. Buenos Aires. Argentina. 2016. Available online: http://forestoindustria.magyp.gob.ar/archivos/gestion-forestalsostenible/publi_ambiental.pdf (accessed on 20 November 2021).

26. INTI-CIRSOC 601. Reglamento Argentino de Estructuras de Madera; INTI-CIRSOC: Buenos Aires, Argentina, 2016.

27. IRAM 9660. Instituto Argentino de Normalización y Certificación. Madera Laminada Encolada Estructural. Parte 1: Clases de Resistencia y Requisitos de Fabricación y de Control; IRAM: Buenos Aires, Argentina, 2015.

28. Foro de Análisis Económico de la Construcción. El Déficit Habitacional en Argentina. Economics Trends. Argentina. 2019. Available online: https:/ / economictrends.com.ar/2019/08/14/el-deficit-habitacional-en-argentina/ (accessed on 20 November 2021).

29. Vogel, H. Diagnóstico Integral de la Cadena de Valor de la Construcción con Madera y Aspectos Estratégicos para Su Desarrollo; Ministerio de Agricultura, Ganadería y Pesca: Buenos Aires, Argentina, 2020.

30. Resolución 3-E/2018. Reconocimiento del Sistema de Construcción de Entramado de Madera Para uso de Estructuras Portantes de Edificios como Sistema Constructivo Tradicional; Ministerio del Interior, Obras Públicas y Hábitat: Buenos Aires, Argentina, 2018.

31. Resolución 9-E/2017. Estándares Mínimos de Calidad para Viviendas de Interés Social; Ministerio del Interior, Obras Públicas y Hábitat: Buenos Aires, Argentina, 2017.

32. De Souza, H.; Salvatore, D. Wooden Structures in Brazil: Present Situation and Perspectives; University of Chicago Press: London, UK, 2014.

33. Rewood. Primeiro Edifício de Madeira. Available online: https:/ / rewood.com.br/cases / edificio (accessed on 20 November 2021).

34. Civilização Engenheira. Conheça Mais Sobre a Maior Estrutura de Madeira do Brasil! Available online: https:// civilizacaoengenheira.wordpress.com/2017/10/20/conheca-mais-sobre-a-maior-estrutura-de-madeira-do-brasil/ (accessed on 20 November 2021).

35. Associação Brasileira de Normas Técnicas. ABNT NBR7190. Projeto de Estruturas de Madeira; Associação Brasileira de Normas Técnicas: Rio de Janeiro, Brazil, 1997.

36. EN 1995-1-1:2004+AC:2006+A1:2008, Eurocode 5. Design of Timber Structures—Part 1-1: General—Common Rules and Rules for Buildings; CEN, European Committee for Standardization: Brussels, Belgium, 2008.

37. Board of the Cartagena Agreement PADT-REFORT. Andean Group Wood Design Manual, 3rd ed.; Board of the Cartagena Agreement PADT-REFORT: Lima, Peru, 1984.

38. Refocosta. Available online: https://www.refocosta.com/ (accessed on 20 November 2021).

39. TECNIFOREST LTDA. Diagnosis for the control of forest use, mobilization, and storage of forest products. In Intersectoral Agreement for Legal Timber in Colombia; TECNIFOREST LTDA: Minambiente, Bogota, 1997.

40. Ministerio del Medio Ambiente. Visión Amazonía. Available online: https://visionamazonia.minambiente.gov.co/proteccionde-la-amazonia/ (accessed on 20 November 2021).

41. FEDEMADERAS. Cuenta Ambiental y Económica: Flujos Productos del Bosque pp. 2014-2017, DANE. Available online: https:/ / fedemaderas.org.co/wp-content/uploads/2012/04/Presentaci\%c3\%b3n-gremial-y-sectorial-21.09.2020.pdf (accessed on 20 November 2021).

42. Food and Agriculture Organization of the United Nations (FAO). Yearbook; FAO: Rome, Italy, 2018.

43. De La Torre, R. Opportunities and Strategies to Develop Forestry Potential in Colombia. Forest Industry and Conservation Seminar, Development Engine in Colombia; Antioquia Society of Engineers: Medellin, Colombia, 2021. 
44. Universidad Nacional de Colombia. Sede Bogotá. Programa de Relaciones Internacionales, Facultad de Ingeniería. Available online: https:/ / ingenieria.bogota.unal.edu.co/es / (accessed on 20 November 2021).

45. Ministerio de Medio Ambiente. Vivienda y Desarrollo Territorial y Comisión Asesora Permanente para el Régimen de Construcciones Sismo Resistentes; Reglamento Colombiano de Construcción Sismo Resistente, NSR-10: Bogota, Colombia, 2010.

46. American Wood Council. National Design Specification (NDS); American Wood Council: Leesburg, VA, USA, 2005.

47. American Wood Council. National Design Specification (NDS); American Wood Council: Leesburg, VA, USA, 2018.

48. American Wood Council. Special Design Provisions for Wind and Seismic (SDPWS); American Wood Council: Leesburg, VA, USA, 2021.

49. EN 1998-1:2004+A1:2013. Eurocode 8-Design of Structures for Earthquake Resistance—Part 1: General Rules, Seismic Actions and Rules for Buildings; CEN, European Committee for Standardization: Brussels, Belgium, 2013.

50. Meza, V. et al. Reforestación Comercial en Costa Rica: Regiones Huetar Norte, Huetar Atlántica y Chorotega, Primera ed.; Universidad Nacional/INSEFOR: Heredia, Costa Rica, 2019; p. 61.

51. Ugalde, S.; Vega, L. Usos y Aportes de la Madera en Costa Rica, 2021 ed.; Oficina Nacional Forestal: San José, Costa Rica, 2021; pp. 10-11.

52. Escuela de Ingeniería Forestal, Tecnológico de Costa Rica. Available online: https:/ /www.tec.ac.cr/escuelas/escuela-ingenieriaforestal (accessed on 20 November 2021).

53. Sistema de Estudios de Posgrado, Universidad de Costa Rica. Available online: https:/ /www.sep.ucr.ac.cr/posgrados/ingenieriacivil/folletos/maestria_academica_ingenieria_estructural.pdf (accessed on 20 November 2021).

54. González-Beltrán, G. Local Ductility in Timber Beam to Column Connections. In Proceedings of the World Conference on Timber Engineering, Vienna, Austria, 22-25 August 2016.

55. Colegio Federado de Ingenieros y de Arquitectos. Código Sísmico de Costa Rica 2010. Revisión 2014, 5th ed.; Editorial Tecnológica de Costa Rica: Cartago, Costa Rica, 2016.

56. American Wood Council. Special Design Provisions for Wind and Seismic (SDPWS); American Wood Council: Leesburg, VA, USA, 2005.

57. Universidad del Bío-Bío. Magíster en Construcción en Madera. Available online: http://www.ubiobio.cl/miweb/webubb.php? id_pagina=696 (accessed on 20 November 2021).

58. Guindos, P. Conceptos Avanzados del Diseño y la Construcción con Madera. Parte I: Uniones, Refuerzos, Elementos Compuestos y Diseño Antisísmico; Ediciones UC: Santiago de Chile, Chile, 2019. (In Spanish)

59. Instituto Forestal (INFOR). Available online: https://www.infor.cl/index.php/news (accessed on 20 November 2021).

60. Centro UC de Innovación en Madera (CIM UC). Propuesta de Modificación Norma NCh 433 Para Estructuras en Madera. Available online: https://madera.uc.cl/es/investigacion/proyectos-de-investigacion/251-propuesta-de-modificacion-normanch-433-para-estructuras-en-madera (accessed on 20 October 2021).

61. Agencia Nacional de Investigación y Desarrollo (ANID). Bases Técnicas para la Inclusión de Losas Industrializables de Baja Huella de Carbono en la Normativa Chilena; Ministerio de Vivienda y Urbanismo de Chile (MINVU)—División Técnica de Estudio y Fomento Habitacional (DITEC); Inmobiliaria Grupo ISIETE (ISIETE): Santiago, Chile, 2020.

62. Diseña Madera. Soluciones Constructivas Para la Edificación. Available online: https:/ /www.disenamadera.cl/ (accessed on 20 October 2021).

63. EN 1995-1-2:2004. Eurocode 5-Design of Timber Structures-Part 1-2: General—Structural Fire Design; CEN, European Committee for Standardization: Brussels, Belgium, 2004.

64. Centro UC de Innovación en Madera (CIM UC). Torre Experimental Peñuelas. Available online: https://madera.uc.cl/es/ investigacion/proyectos-de-investigacion/249-torre-penuelas (accessed on 20 October 2021).

65. CONAF. Los Bosques de Chile, Pilar Para el Desarrollo Inclusivo y Sostenible. Revista Chile Forestal. 2020. Available online: https://www.conaf.cl/cms/editorweb/chifo/394/11/ (accessed on 20 October 2021).

66. Instituto Forestal (INFOR). Anuario Forestal, Chilean Statistical Yearbook of Forestry 2020. Available online: https://wef.infor.cl/ publicaciones/anuario/2020/Anuario2020.pdf (accessed on 20 October 2021).

67. Cámara Chilena de la Construcción. Déficit Habitacional: Un Desafío Pendiente. 2019. Available online: https://cchc.cl/2019 / deficit-habitacional (accessed on 8 October 2021).

68. Corporación Chilena de la Madera (CORMA). Más de 22 mil Personas Online Visitaron la Semana de la Madera 2021. Available online: https:/ / www.corma.cl/mas-de-22-mil-personas-online-visitaron-la-semana-de-la-madera-2021/ (accessed on 5 November 2021).

69. Arguëlles, R.; Arriaga, F. Estructuras de Madera. Diseño y Cálculo, 2nd ed.; Bellisco: Madrid, Spain, 2003.

70. Cátedra Madera Universidad de Navarra. Available online: https://www.unav.edu/web/catedra-madera (accessed on 5 November 2021).

71. Máster en Ingeniería de la Madera Estructural. Available online: https://www.usc.gal/es/centros/cep/posgrao/curso.html? tcurso $=2 \&$ idc $=4540 \&$ anoAc $=2017-2018$ (accessed on 5 November 2021).

72. Madera, Mueble y Corcho. Available online: https://www.todofp.es/que-como-y-donde-estudiar/que-estudiar/loe/maderamueble-corcho.htm (accessed on 5 November 2021).

73. Lignomad. Red Para el Impulso de la Madera y Otros Materiales Lignocelulósicos en el Sector de la Construcción. Available online: https: / / www.lignomad.com (accessed on 5 November 2021). 
74. FP1402-Basis of Structural Timber Design—COST Action. Available online: https://www.cost.eu/actions/FP1402/ (accessed on 5 November 2021).

75. CA20139—Holistic Design of Taller Timber Buildings_COST Action. Available online: https://www.cost.eu/actions/CA20139/ (accessed on 5 November 2021).

76. AITIM, Asociación de Investigación de las Industrias de la Madera. Available online: https://infomadera.net/ (accessed on 5 November 2021).

77. BEC-Egurtek Bilbao Exhibition CentreReferencia para Egurtek. Available online: https://egurtek.bilbaoexhibitioncentre.com/ en/ (accessed on 5 November 2021).

78. Noticias de la Red Lignomad. Red para el Impulso de la Madera y Otros Materiales Lignocelulósicos en el Sector de la Construcción. Available online: https:/ / www.lignomad.com/noticias (accessed on 5 November 2021).

79. Forum Holzbau. Available online: https://www.forum-holzbau.com/ (accessed on 5 November 2021).

80. Documento Básico SE-M. Available online: https://www.codigotecnico.org/pdf/Documentos/SE/DBSE-M.pdf (accessed on 5 November 2021).

81. Código técnico de la Edificación. Available online: https: / / www.codigotecnico.org/ (accessed on 5 November 2021).

82. Schenk, M.; Winter, S. Second generation of Eurocode 5-Publication schedule and interface between design and products standards. In Proceedings of the World Conference on Timber Engineering 2021, Santiago de Chile, Chile, 9-12 August 2021.

83. Arriaga, F. Estado actual de la construcción con madera en España. Quaderns d'Estructures 2020, 69, 5-20.

84. Ramon, L.S. Arquitecte. Edifici de Fusta Contralaminada de 6 Plantes (Edificio de Madera Contralaminada de 6 Plantas) CLT 6 Stories Building in Lleida (Spain). Available online: https: / / ramonllobera.blogspot.com (accessed on 5 November 2021).

85. 32+33 SOCIAL HOUSING IN HONDARRIBIA-TyM Asociados. Available online: https://www.tymasociados.com/index.php/ portfolio_page/3233-social-housing-in-hondarribia/ (accessed on 5 November 2021).

86. La Borda-Housing to Build Community. Available online: http://www.laborda.coop/en/ (accessed on 5 November 2021).

87. Advanced Architecture Awards 2021. Available online: https://www.rebuildexpo.com/awards/awards-2021/ (accessed on 5 November 2021).

88. Sociedad Pública de Vivienda y Urbanismo del Gobierno de Navarra. Available online: https://www.construible.es/2018/0 6/14/jose-maria-aierdi-director-gerente-nasuvinsa-sociedad-publica-vivienda-urbanismo-gobierno-navarra (accessed on 5 November 2021).

89. Nasuvinsa. Navarra de Suelo y Vivienda, S.A. Available online: https:/ / www.nasuvinsa.es/ (accessed on 5 November 2021).

90. Viviendas de Alquiler Para Mayores en un Edificio Puntero. Available online: https://www.nasuvinsa.es/en/node/1502 (accessed on 5 November 2021).

91. Gestión Forestal Sostenible. En Anuario de Estadística Forestal 2019. Ministerio para la Transición Ecológica y el Reto Demográfico. Madrid, España, 2019. Available online: https://www.miteco.gob.es/es/biodiversidad/estadisticas/aef2019_06_gfs_tcm30-5291 59.pdf (accessed on 5 November 2021).

92. PEFC España. Available online: https:/ / pefc.es/ (accessed on 5 November 2021).

93. Balance de la madera. Comercio exterior. In En Anuario de Estadística Forestal 2019; Ministerio para la Transición Ecológica y el Reto Demográfico: Madrid, España, 2019. Available online: https:/ /www.miteco.gob.es/es/biodiversidad/estadisticas/aef2019_ 13_balancemadera_tcm30-529164.pdf (accessed on 5 November 2021).

94. Aguilar, J.I. Pinos de Guatemala; Ministerio de Agricultura: Guatemala City, Guatemala, 1961.

95. Sistema de Información Forestal de Guatemala. Programa de Incentivos Forestales-PINFOR-(Forestry Incentive Program). 2021. Available online: http:/ / www.sifgua.org.gt/Pinfor.aspx (accessed on 20 October 2021).

96. Instituto Técnico de Capacitación y Productividad. Especialidad Carpintería y Construcción. 2021. Available online: https: / / www.intecap.edu.gt/centros/centroguatemala1/carpinteria-construccion/ (accessed on 20 October 2021).

97. ASTM D2555-17a. Standard Practice for Establishing Clear Wood Strength Values; ASTM International: West Conshohocken, PA, USA, 2017.

98. ASTM D245-06(2019). Standard Practice for Establishing Structural Grades and Related Allowable Properties for Visually Graded Lumber; ASTM International: West Conshohocken, USA, 2019.

99. Guindos, P.; De León, E. Recopilación de Información Sobre Tres (3) Especies de Pino para la Elaboración de Normalización de la Madera en la Construcción en Guatemala; Asociación para la Protección de los Recursos Naturales Renovables: Ciudad de Guatemala, Guatemala, 2021.

100. Guatemala Green Building Council. Certificación CASA Guatemala. 2021. Available online: https://www.guatemalagbc.org/ casa-guatemala/ (accessed on 20 October 2021).

101. SEMARNAT-CONAFOR. Estado que Guarda el Sector Forestal en México 2019, 1st ed.; SEMARNAT-CONAFOR: Guadalajara, México, 2019; p. 6.

102. FITECMA. Plan de Estudios del Programa de Doctorado en Ciencias y Tecnología de la Madera; UMSNH: Morelia, México, $2020 ;$ p. 18.

103. Gutierrez, Y. Industria de la Vivienda de Madera en México. 2014. Available online: https://www.miambiente.com.mx/general/ industria-de-la-vivienda-de-madera-en-mexico / (accessed on 20 October 2021).

104. ONNCCE. Normas Oficiales Mexicanas. Available online: https://www.onncce.org.mx/es/certificacion-bottom (accessed on 20 October 2021). 
105. Amaya, J.; Carhuavilca, D. Cuenta de Bosques del Perú; Servicio Nacional Forestal y de Fauna Silvestre (SERFOR) \& Instituto Nacional de Estadística e Informática (INEI): Lima, Peru, 2021; Available online: https:/ / www.inei.gob.pe/media/MenuRecursivo/ publicaciones_digitales/Est/Lib1811/libro.pdf (accessed on 4 October 2021).

106. Gutiérrez, C. Censos Nacionales 2017: XII de Población, VII de Vivienda y III de Comunidades Indígenas. Perú: Características de las Viviendas Particulares y los Hogares. Acceso a Servicios Básicos; Instituto Nacional de Estadística e Informática (INEI): Lima, Peru, 2018; Available online: https://www.inei.gob.pe/media/MenuRecursivo/publicaciones_digitales/Est/Lib1538/index.html (accessed on 4 October 2021).

107. Ordoñez, P.; Lugo, Y. Estructuras de Madera Aplicadas al Sector de la Construcción en el Perú. Bachelor Thesis, Pontifical Catholic University of Peru, Lima, Peru, 2016. Available online: http:/ /hdl.handle.net/20.500.12404/6834 (accessed on 4 October 2021).

108. Sears, R.; Cronkleton, P.; Villanueva, F.; Miranda, M.; Pérez-Ojeda del Arco, M. Farm-forestry in the Peruvian Amazon and the feasibility of its regulation through forest policy reform. Forest Policy Econ. 2018, 87, 49-58. [CrossRef]

109. Organización de las Naciones Unidas para la Alimentación y la Agricultura (FAO). La Industria de la Madera en el Perú. Identificación de las Barreras y Oportunidades para el Comercio Interno de Productos Responsables de Madera, Provenientes de Fuentes Sostenibles y Legales en las MIPYMES de Perú; FAO: Lima, Peru, 2018; Available online: https://www.fao.org/documents/card/es/c/i8335es/ (accessed on 4 October 2021).

110. National Building Code (RNE). Technical Standard Wood; RNE E.010: Lima, Peru, 2021.

111. AGROPORTAL. Available online: https://www.agroportal.pt/os-numeros-que-valorizam-a-floresta-nacional/ (accessed on 28 October 2021).

112. Departamento de Engenharia Civil da Universidade de Coimbra. Available online: https://apps.uc.pt/courses/PT/unit/90295/ 21181/2021-2022? type $=$ ram\&id=9061 (accessed on 28 October 2021).

113. Negrão, J. Estruturas de madeira em Portugal-Presente e passado recente. In Proceedings of theCIMAD11-1 Congresso Ibero-Latino-Americano da Madeira na Construção, Coimbra, Portugal, 7-9 June 2011.

114. Indústria da cortiça. Direção Geral das Atividades Económicas; Governo de Portugal: Lisbon, Portugal, 2021.

115. EN 1995-2:2004. Eurocode 5-Design of Timber Structures—Part 2: Bridges; CEN, European Committee for Standardization: Brussels, Belgium, 2004.

116. Instituto Português de Qualidade. Available online: http://www1.ipq.pt/PT/Pages/Homepage.aspx (accessed on 28 October 2021).

117. Ministerio de Ganadería Agricultura y Pesca. Estadísticas Forestales 2020; Ministerio de Ganadería Agricultura y Pesca: Montevideo, Uruguay, 2020.

118. Sociedad de Productores Forestales. Boletín Electrónico; Sociedad de Productores Forestales: Montevideo, Uruguay, 2019.

119. Uruguay XXI 2020—Foreign Trade Report; Investment, Export and Country Brand Promotion Agency: Montevideo, Uruguay, 2019.

120. Dieste, A. Programa de Promoción de Exportaciones de Productos de Madera. 2012. Available online: http://www.miem.gub. uy/consejos-sectoriales/madera/publicaciones (accessed on 25 October 2021).

121. Enkel Group. Radial Interview. Available online: https:/ /www.enkelgroup.com/2021/05/05/enkel-programa-en-perspectiva/ (accessed on 25 October 2021).

122. UNIT 1261:2018. Clasificación Visual de la Madera Aserrada para uso Estructural-Madera de Pino Taeda y Pino Elliotis (Pinus taeda y Pinus elliottii); Instituto Uruguayo de Normas Técnicas: Montevideo, Uruguay, 2018.

123. UNIT 1262:2018. Madera Aserrada de uso Estructural. Clasificación Visual. Madera de Eucalipto (Eucalyptus grandis); Instituto Uruguayo de Normas Técnicas: Montevideo, Uruguay, 2018.

124. UNIT 1264:2019. Estructuras de Madera. Madera Laminada Encolada. Requisitos de Fabricación; Instituto Uruguayo de Normas Técnicas: Montevideo, Uruguay, 2019.

125. UNIT 1265:2020. Estructuras de Madera. Madera Laminada Encolada. Requisitos; Instituto Uruguayo de Normas Técnicas: Montevideo, Uruguay, 2020.

126. Congreso Latinoamericano de Estructuras de Madera (CLEM). 4 Edición. Montevideo, Uruguay. 2019. Available online: http:/ / www.clem2019.uy/es/Pages/home (accessed on 25 October 2021).

127. Congreso Ibero-Latinoamericano de la Madera en la Construcción (CIMAD). 3 Edición. Madrid, España. 2021. Available online: http:/ / www2.montes.upm.es/CIMAD2021/bienvenidos/historia/ (accessed on 25 October 2021).

128. Red para Industrialización y Digitalización de la Industria de la Construcción en Madera (RIDICM). Available online: https: / / www.cyted.org/es/ridicm (accessed on 10 November 2021). 